\title{
Counterfeit formulations: analytical perspective on anorectics
}

\author{
Dan Osei Mensah Bonsu ${ }^{1,2,3,4}$ (1) $\cdot$ Constance Afoakwah ${ }^{1} \cdot$ Maria de la Paz Aguilar-Caballos $^{4}$
}

Received: 8 July 2020 / Accepted: 4 December 2021 / Published online: 2 January 2021

(c) The Author(s) 2020

\begin{abstract}
Purpose This paper examines the scope of anorectics in counterfeit weight-reducing formulations and provides insight into the present state of research in determining such adulterants. Analytical techniques utilised in profiling adulterants found in slimming products, including limitations and mitigation steps of these conventional methods are also discussed. The current legal status of the anorectics and analogues routinely encountered in non-prescription slimming formulations is also explored. Methods All reviewed literature was extracted from Scopus, Web of Science, PubMed, and Google Scholar databases using relevant search terms, such as, 'counterfeit drugs', 'weight loss drugs', 'weight-reducing drugs', 'slimming drugs', 'anorectic agents', and 'counterfeit anorexics'. Legislation related to anorectics was obtained from the portals of various government and international agencies.

Results Anorectics frequently profiled in counterfeit slimming formulations are mostly amphetamine derivatives or its analogues. Five routinely reported pharmacological classes of adulterants, namely anxiolytics, diuretics, antidepressants, laxatives, and stimulants, are mainly utilised as coadjuvants in fake weigh-reducing formulations to increase bioavailability or to minimise anticipated side effects. Liquid and gas chromatography coupled with mass spectrometric detectors are predominantly used techniques for anorectic analysis due to the possibility of obtaining detailed information of adulterants. However, interference from the complex sample matrices of these fake products limits the accuracy of these methods and requires robust sample preparation methods for enhanced sensitivity and selectivity. The most common anorectics found in counterfeit slimming medicines are either completely banned or available by prescription only, in many countries.

Conclusions Slimming formulations doped with anorectic cocktails to boost their weight-reducing efficacy are not uncommon. Liquid chromatography combined with mass spectrometry remains the gold standard for counterfeit drug analysis, and requires improved preconcentration methods for rapid and quantitative identification of specific chemical constituents. Extensive method development and validation, targeted at refining existing techniques while developing new ones, is expected to improve the analytical profiling of counterfeit anorectics significantly.
\end{abstract}

Keywords Anorectics - Counterfeit weight loss formulations - Adulterants in slimming products $\cdot$ Amphetamine derivatives $\cdot$ Antihyperglycemic agents $\cdot$ LC-MS/MS

\section{Introduction}

Supplementary Information The online version contains supplementary material available at https://doi.org/10.1007/s1141 9-020-00564-5.

Dan Osei Mensah Bonsu

danoseimensah.bonsu@adelaide.edu.au

1 Department of Forensic Sciences, University of Cape Coast, PMB UCC, Central Region, Cape Coast, Ghana

2 Australian Centre for Ancient DNA (ACAD), School of Biological Sciences, The University of Adelaide, North Terrace, Adelaide, SA 5000, Australia
Counterfeit pharmaceutical products represent an enormous global burden, and their sales have seen a tremendous surge in recent years, with its attendant threat to human health and

3 School of Chemistry, University of Lincoln, Brayford Pool, Lincolnshire, Lincoln LN6 7TS, UK

4 Departamento de Química Analítica. Instituto Universitario de Química Fina y Nanoquímica (IUNAN), Facultad de Ciencias. Universidad de Córdoba, Campus Universitario de Rabanales, 14014 Córdoba, España 
public safety $[1,2]$. An estimated $10 \%$ of the global pharmaceutical market consists of fake and substandard drugs [3]. Many countries in sub-Saharan Africa, Southeast Asia and Latin America, serve as fertile grounds, where about 30 to $60 \%$ of sold medicines are fraudulent [4]. The Pharmaceutical Security Institute (PSI) based on a seventeen consecutive year data on counterfeiting, recognized a permanent increase in case reports as well as an extensive growth in the manufacture, distribution, transportation, and international trade in fake medicines [5].

Any kind of medications that are in high demand by consumers and with profitable market prospects are targets for counterfeiting [6]. Due to the potential for huge profits in their markets, Europe (especially the United Kingdom) and the United States, have recorded an increase in seized counterfeit therapeutics, mostly facilitated by Internet transactions $[5,7]$. As a result of the increasing demand for cheap medicines and low production cost, counterfeit pharmaceutical trade continues to be a massively lucrative business with sophisticated global networks. For instance, in a global crackdown by Interpol [8], about " \$41-million haul of illegal pharmaceuticals being sold online" were confiscated, with 9.9 million doses of counterfeit drugs seized in the United Kingdom [7] as reported by the Medicines and Healthcare Products Regulatory Agency (MHRA). Fake medications advertised for treatment of erectile dysfunction, hair loss and slimming (weight loss) were the frequently encountered drugs in the seized hauls. The United Nations Office on Drugs and Crime (UNODC) recognizes counterfeit medicines as a global public health threat [9] with a projected sale of approximately $\$ 200$ billion in 2013 [10, 11].

Typically adulterated medicines with extensive global reach include those for sleeping disorders [12], non-steroidal anti-inflammatory drugs, antibiotics [13-15], anticancer drugs $[16,17]$, erectile dysfunction drugs $[18,19]$ and anorectics [20-22]. Anorectics (or anorexics) refer to medicines or dietary supplements used for weight-loss purposes [23]. Medicines sold over-the-counter and from Internet sources adulterated with anorectics and/or their analogues or metabolites have been reported [24-29]. Similarly, phytotherapeutic (i.e., plant-based) formulations that are deemed "natural product" alternative treatment for obesity have been demonstrated to contain non-declared anorectics and adjuvants that boost their efficacy [24, 30-35]. There are, however, scarce reports that systematically review data from a forensic perspective. This paper, therefore, explores the current evidence related to anorectics in counterfeit weight-reducing formulations, including their forensic profiling, analytical techniques and legal status.

\section{Collection of the literature}

Literature search, data selection and extraction were performed in Scopus, Web of Science and PubMed databases (2000-2019) for relevant peer-reviewed original articles. The search terms used were 'counterfeit drugs', 'weight loss drugs', 'weight-reducing drugs', 'slimming drugs', 'anorectic agents', and 'counterfeit anorexics'. Google Scholar database search was used as an additional screening of initially identified publications to expand the source of data as well as to ensure the completeness of the search strategy. Current legislation on the anorectics was obtained from online portals/repositories of international statutory bodies and country-specific agencies.

\section{Anorectics in counterfeit weight loss products}

An anorectic or anorexic is a general term used to describe any agent, such as drugs, medicines and/or dietary supplements, which is used for weight loss purposes. For instance, de Carvalho et al. [25] reported that about $80 \%$ of amphetamines produced legally are utilized for weight loss therapies. A significant factor that has accounted for the recent rise in anorectic use is obesity [36]. This condition, considered as a global public health problem [37], affects millions of individuals. Since medications for management and treatment of obesity are mostly prescription only in many countries [38], online pharmacies and unreliable Internet sources serve as an off-prescription route to purchase slimming products $[22,39]$. Also, misleading advertisements, entrenched by the modern craze for the "ideal figure" beauty standards propagated by the mainstream media have contributed to unbridled view and quest of people for slimming products [3]. Counterfeiting contravenes the legislations of many countries $[1,40]$, because such formulations tend to have constituents inconsistent with their real declared and registered ones. The presence of these falsely declared active anorectic ingredients, therefore, makes their effects on human body random and unpredictable [32]. Apart from the adverse health effects and deaths associated with the toxic additives, such counterfeiting poses threats to pharmaceutical industries, as well as the economy and health care systems of countries $[2,10]$. Moreover, the unpredictability regarding the chemicals that can be present as undeclared constituents of fake formulations requires the development of sensitive and selective analytical methods for their identification and quantification.

Anorectics agents found as adulterants in drugs, medicines and/or dietary supplements induce loss of appetite, 
minimize intestinal fat (lipid) absorption as well as increasing the sensing of satiety [24]. Although there is a category of specifically designed drugs called anorectics (e.g., phentermine) mainly for the management of obesity, several other drug classes, mostly centrally acting ones, such as the amphetamines and similar sympathomimetic amines, have anorectic properties. The pharmacokinetics of important anorectic agents (Fig. 1) commonly encountered as adulterants in counterfeit drugs are discussed here.

\section{Sibutramine}

Sibutramine (N-(1-(1-(4-chlorophenyl)-cyclobutyl)3 methylbutyl)- $N$, $N$-dimethylamine hydrochloride) (trade names Meridia ${ }^{\circledR}$ in the USA, Reductil ${ }^{\circledR}$ in Europe and Australia), an amphetamine derivative, is an anorectic drug, which acts by inhibiting serotonin (5-hydroxytryptamine: 5-HT), norepinephrine, and to a small extent, dopamine reuptake [41-43]. Following the inhibition of these neurotransmitters, an enhanced sense of satiety and decrease in appetite, lead to reduced food intake [44]. Through thermogenic effects in basal and fed state, sibutramine and its two pharmacologically active metabolites, $N$-monodesmethyl and $N$-di-desmethyl sibutramine, have also been reported to increase energy expenditure [45-49]. Weight loss is as a result of the antiatherogenic effect of sibutramine, which enhances insulin resistance, metabolism of glucose, and dyslipidemia. Sibutramine is a routine adulterant in slimming products, especially in phytotherapeutic (herbal) food supplements [18, 24, 35].

\section{Fenfluramine}

Fenfluramine (ethyl(\{1-[3-(trifluoromethyl) phenyl] propan2-yl\}) amine) is another anorectic associated with counterfeit slimming pharmaceuticals. Like sibutramine, it is also an amphetamine derivative and a serotonin reuptake inhibitor. It was mainly prescribed for the management of obesity [50]. The drug and its metabolites/analogues (dexfenfluramine, $N$-nitrosofenfluramine) act by affecting the brain's metabolism such that serotogenic transmission is enhanced in the hypothalamic feeding and satiety centres leading to reduced calorie intake [51]. Fenfluramine and its analogues are major synthetic chemicals found as adulterants in counterfeit weight loss medicines, with reported severe pulmonary hypertension and deaths $[22,52]$.

\section{Metformin}

Metformin (1-carbamimidamido- $N, N$-dimethylmethanimidamide hydrochloride) is a biguanide antihyperglycemic drug used to manage type 2 diabetes [53]. It is pharmacologically different in action to other classes of antihyperglycemic agents. It enhances glucose tolerance in type 2 diabetic patients by reducing hepatic glucose production, lowering intestinal absorption of glucose, increasing peripheral glucose uptake and improving insulin sensitivity [54-56]. Metformin is continuously detected in fake slimming formulations [57], because unlike sulfonylureas, it does not cause hypoglycaemia nor hyperinsulinemia even when administered alone in healthy subjects or patients with type 2 diabetes [58]. In some instances, however, metformin, like its withdrawn structural analogues buformin and phenformin, is known to cause lactic acidosis as a result of the very minimal liver uptake of serum lactate which is a required substrate of gluconeogenesis $[59,60]$.

\section{Phentermine}

Phentermine ( $\alpha, \alpha$-dimethylphenethylamine), traded under brand names Adipex, Adipex-P, Fastin, Lonamin, Phentercot, Phentride and Pro-Fast [61-64] is the oldest and commonest anorectic prescribed for the management of obesity [65]. It is a noradrenergic sympathomimetic agent approved by the FDA for short-term ( $<12$ weeks) treatment in combination with regular exercise and reduction in caloric diet, for the treatment of obesity [66]. However, phentermine has been used off-label as a long-term treatment for obesity without any serious adverse effects [67]. Initially ascribed as a central nervous system stimulant which triggers the release of norepinephrine in the hypothalamus [68], recent evidence suggests that phentermine inhibits the reuptake of norepinephrine and dopamine [68]. Subsequently, this suppresses appetite [69] and decreases body weight by reducing food intake and increasing resting energy expenditure [70, 71]. Phentermine is a key synthetic drug often illegally added to herbal slimming formulations and nutraceutical supplements $[72,73]$ to boost their efficacy. The use of this anorectic in such formulations has been associated with some adverse cardiovascular effects, such as primary pulmonary hypertension, palpitations, tachycardia, ischemic events [69], and dry mouth.

\section{Amfepramone (diethylpropion)}

Amfepramone (2-diethylaminopropiophenon) stimulates the central nervous system to suppress appetite by increasing the release of catecholamines (dopamine and noradrenaline) in the hypothalamus and further limits their reuptake [74]. Subsequently, the drug is used as a short-term anorectic agent for the treatment of obesity [75]. Amfepramone is the most frequently abused and illicitly trafficked pharmacological adulterants in herbal weight loss products worldwide [32]. De Carvalho et al. [76] detected levels of amfepramone in all 106 herbal weight loss products analyzed. Similarly, Almeida et al. [77] found amfepramone as an adulterant in 


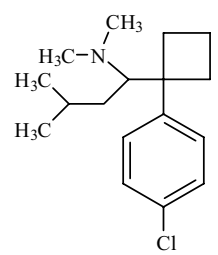

Sibutramine<smiles>CCNC(C)Cc1cccc(C(F)(F)F)c1</smiles>

Fenfluramine<smiles>CN(C)C(=N)NC(=N)N</smiles>

Metformin<smiles>CNC(CC(C)C)C1(c2ccc(Cl)cc2)CCC1</smiles>

$\mathrm{N}$-Monodesmethylsibutramine<smiles>CCNC(C)Cc1cccc(C(F)(F)F)c1</smiles>

Dexfenfluramine<smiles>CC(C)CC(NN)C1(c2ccc(Cl)cc2)CCC1</smiles>

$\mathrm{N}$-Didesmethylsibutramine<smiles>CCN(N=O)C(C)Cc1cccc(C(F)(F)F)c1</smiles>

$\mathrm{N}$-Nitrosofenfluramine<smiles>CC(C)(N)Cc1ccccc1</smiles>

Phentermine<smiles>CCN(CC)C(C)C(=O)c1ccccc1</smiles>

Amfepramone<smiles>CCCCNC(=N)NC(=N)N</smiles>

Buformin<smiles>N=C(N)NC(=N)NCCc1ccccc1</smiles>

Phenformin<smiles>CC[C@H]1CN2CCc3c([nH]c4cccc(OC)c34)[C@@H]2C[C@H]1/C(=C\OC)C(=O)OC</smiles>

Mytraginine<smiles>COC(=O)C(c1ccccc1)C1CCCCN1C</smiles>

Methylphenidate<smiles>NC(=O)CS(=O)C(c1ccccc1)c1ccccc1</smiles>

Modafinil<smiles>O=C(CS(=O)C(c1ccccc1)c1ccccc1)NO</smiles>

Adrafinil

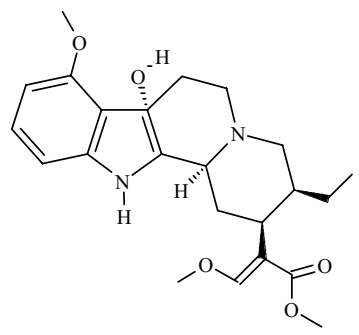

7-Hydroxymytraginine

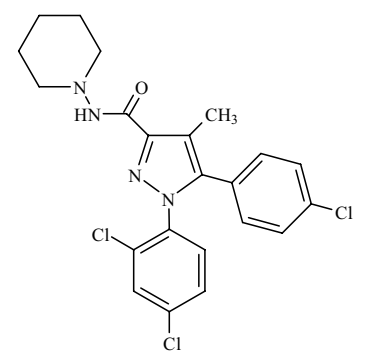

Rimonabant

Fig. 1 Structures of anorectics frequently found in counterfeit weight loss formulations

herbal weight loss products at levels of $5 \%$ in 20 samples examined. Nonetheless, amfepramone has been associated with some moderate adverse effect, such as dry mouth, insomnia, anxiety, irritability, constipation, headache, dizziness and polydipsia [78]. The anorectic was previously linked to the development of pulmonary hypertension [79], but has since been disproved [80].

\section{Methylphenidate}

Typically sold under the label Ritalin, methylphenidate is a central nervous system stimulant initially utilised as an analeptic for reversal of barbiturate-induced coma [81]; however, it is currently used to treat attention-deficit hyperactivity disorder (ADHD) [82]. Methylphenidate promotes 
the release of stored or newly synthesized dopamine and inhibits reuptake by binding to the dopamine receptor [83] This results in increased extracellular dopamine levels that facilitate slimming via suppression of appetite [81] as demonstrated by the sudden weight loss in ADHD patients [84]. The stimulant has been shown to increase blood pressure with the attendant risk of cardiovascular disease and strokes [85]. The seemingly explosive increase in prescriptions of Ritalin [86] could result in the medicine being abused as a weight-loss drug [87], and such incidence has been reported on a limited scale [87].

\section{Modafinil}

Modafinil and its analogue have been detected in various slimming herbal products. Deconinck et al. [88] identified modafinil at a concentration of $0.125-1.00 \mathrm{mg} / \mathrm{mL}$ in herbal slimming products. Vanhee et al. [89] reported the presence of adrafinil, an analogue of modafinil in a food supplement that was submitted by the Federal Agency for Safety of the Food Chain (FASFC), Belgium. As a eugeroic psychostimulant, modafinil (2-[(diphenylmethyl) sulfinyl] acetamide) sold under the brand name Provigil, is used primarily for the treatment of narcolepsy, shift work sleep disorder and obstructive sleep apnoea [90-93]. While the exact mechanism is unknown, stimulating the release of norepinephrine, dopamine and serotonin and subsequently inhibiting their reuptake has been mooted [94]. Research by Makris et al. [95] reported improved appetite suppression following administration of modafinil and recommended its use for the treatment of obesity. Despite a lower risk of cardiovascular-related adverse effects, the drug has been associated with moderate side effects, such as headache, nausea, diarrhoea, nervousness, anxiety, dyspepsia, and insomnia [96, 97]. Recent works by Lazenka et al. [98] and Avelar et al. [99] have, however, shown that modafinil's action on brain's dopamine centres is identical to that of methamphetamine and cocaine.

\section{Rimonabant}

Rimonabant, sold under the trade name Acomplia or Zimulti is an anorectic, antiobesity drug. It is a selective endocannabinoid $\mathrm{CB}_{1}$ receptor antagonist that effects weight loss through the reduction in appetite [100]. In mature patients with type 2 diabetes, the drug showed some beneficial effects, such as glycemic control, reduced waist circumference and weight. However, rimonabant has since been withdrawn from the market and clinical use due to its neuropsychiatric side effects, notably, the onset of suicidal tendencies in patients [101]. Subsequently, analogues taranabant and otenabant, considered as a promising treatment for obesity due to improved anorectic effects were discarded [102].
Despite the risk of significant adverse effects, ample evidence indicates the availability of Acomplia, either genuine, counterfeited or as adulterants in weight loss formulations, to purchase on the Internet [103].

\section{Mitragynine}

Mitragynine is obtained from the plant Mitragyna speciosa (also known as kratom) and is the most abundant active alkaloid isolated from the plant, with speciogynine, paynantheine, and 7-hydroxymitragynine making up the other essential alkaloids [104]. Kratom is primarily available as a drug of abuse, and its pharmacological effects have been reported to be dose-dependent [105]. Stimulant effects and opiate-like effects are achieved in lower and higher doses, respectively $[106,107]$. Several adverse effects have been documented to be associated with mitragynine use in humans. These include dry mouth, constipation, changes in urination pattern, vomiting, nystagmus, tremor, anorexia and weight loss [108]. Anorexia and weight loss are side effects which are most prominent in chronic users of the drug [109], and this observation has influenced the use of mitragynine - a psychoactive plant extract - as an anorectic [110]. An online market [111] that sells extracts of kratom with different levels of purity and/or enhancement, for instance, declares "there are some detractors who consider kratom's long-term effects of weight loss to be an unwanted side effect" on the website in a concerted effort to advertise and encourage the use of mitragynine for slimming purposes among other "modern benefits".

\section{Other drug classes}

Apart from conventional anorectics, adulterants mainly found in fake slimming products have been grouped into five pharmacological classes, namely anxiolytics, diuretics, antidepressants, laxatives and other stimulants [88]. These drug groups are mainly utilized as coadjuvants in the formulations to possibly increase bioavailability or to minimize the various side effects, such as irritability, headaches, nervous depression, chemical dependence and unstable humour [52], associated with the use of certain anorectics to mostly mask the presence of anorexics.

Anxiolytic action of benzodiazepines, such as diazepam and alprazolam, routinely found in counterfeit slimming formulations is targeted at reducing the anxiety side effects caused by anorexics [112]. Antidepressants are a routine find in fake slimming pharmaceutical formulations. While they are mostly incorporated to counter the detrimental effects of the actual anorectics [25], some antidepressants directly facilitate weight loss. For instance, bupropion, a norepinephrine and dopamine reuptake inhibitor is an atypical antidepressant that causes the most weight loss 
$[113,114]$ and frequently encountered as an adulterant in slimming formulas. However, the slimming action of this drug has been attributed to its side effects, mainly loss of appetite, nausea, and vomiting [115]. The FDA has, thus, approved bupropion for weight loss [116]. Sertraline is another antidepressant used as coadjuvant in fake slimming products since it has been documented to effectively limit the nervous depression most often reported in obese people using anorectics [25]. Tricyclic antidepressants, such as amitriptyline, trimipramine, imipramine and desipramine, selectively inhibit the reuptake of norepinephrine and to some extent, aid in the loss of weight due to this activity [117]. Diuretics (e.g., furosemide) and laxatives (e.g., phenolphthalein) are intentionally added adulterants to increase urine flow and intestinal motility, respectively. These synthetic compounds are often found as adulterants in herbal-based (phytotherapeutic) weight loss formulas [118], but their effect is not associated with a reduction in body fat but mainly increased loss of body water content. Many compounds from plant-based medicines have intrinsic laxative as well as diuretic properties and produce their deleterious effects akin to those from synthetic ones [119]. Therefore, the presence of undeclared laxatives or diuretics in phytotherapeutic carries risks, including dehydration and electrolyte imbalance [120], either independently or as a result of interaction with other constituents within the formulation.

Coffee, tea, guarana or other plant extracts have been reported to be efficient in loss of weight processes owing to caffeine consumption [121,122], although some studies suggest that in-depth research should be performed to demonstrate the usefulness of these extracts or pure caffeine as food supplements for individuals who are following a diet [123]. Caffeine is metabolized to 3,7 dimethylxanthine (theobromine), 1,7 dimethylxanthine, and 1,3-dimethylxanthine (theophylline) by the liver, and the elimination mechanism depends on the initial dose of caffeine ingested.

\section{Legal status}

The legal status of anorectics is mostly determined based on studies that evaluate the safety, tolerability, pharmacokinetics and/or toxicological profile/clinical outcome following the administration of a drug. For instance, due to the risk of heart failure, stroke and psychosis [124], sibutramine was banned in the United States by the Food and Drug Administration (FDA) [125], the European Union by the European Medicine Agency (EMA) [126], and Australia's Therapeutic Goods Administration (TGA) [127]. The ban was based on the data from the six-year Sibutramine Cardiovascular Outcome (SCOUT) trial with 10,742 patients which confirmed an increased risk of major cardiac events with the anorectic use [128]. Subsequently, many countries have withdrawn sibutramine from their markets since 2010. Similarly, fenfluramine was banned and withdrawn from the market by the FDA in 1997 [129] due to its association with rare heartvalve disease in people who administered them as a diet pill [51]. Although the European Commission banned fenfluramine and dexfenfluramine based on "unacceptable safety profile in normal conditions of use, their lack of therapeutic efficacy and the consequent unfavourable risk/benefit balance" [130], the decision has since been revoked by the EU's General Court [131].

Due to concerns of the potential for abuse, phentermine has been classified as Schedule IV controlled substance [132]. Rimonabant, including analogous centrally acting weight-reducing drugs, was banned by the FDA following the emergence of severe mood disorders [133]. Neither Mitragyna speciose nor its alkaloids fell under any listed schedules of the United Nations Drugs Convention $[134,135]$. Some EU member states, however, categorize kratom as controlled, narcotic or "drug of concern" [134] while the US FDA has temporarily placed mitragynine and 7-hydroxymitragynine under Schedule I of the Controlled Substances Act [136], given its direct link with death [137]. Mitragynine is, however, banned in Malaysia, Myanmar, and Australia [138]. The current legal status of the main anorectics examined in this paper is presented in Table 1.

\section{Detection of anorectics in counterfeit slimming products}

Differentiation between known authentic and suspected counterfeit formulations primarily involves physical examination and comparison of features on the drugs and packaging, such as texts on blister packs, packets and leaflet inserts [139]. This process is subjective and depends mainly on the experience of the analyst. Moreover, advancements in technology, which has contributed to sophistication in counterfeiting, mean that a careful visual inspection is inadequate for the purpose and must be followed by chemical analytical methods. Several methods and technologies are available for the screening of suspected counterfeit pharmaceutical formulations. For instance, marking and coding of medicines and/or their packaging are increasingly being undertaken by manufacturers, to check counterfeiting in efforts to protect their brand as well as to facilitate effortless initial examinations by law enforcement personnel [140]. However, following the discovery of a case of drug counterfeiting, it is prudent to obtain information on its chemical composition to enable assessment of potential dangers to patients or users.

For instance, an analysis of the FDA's "tainted weight loss products" [141] list, which consists of over-the-counter (OTC) products frequently advertised as dietary supplements 
Table 1 Legal status of selected anorectics in counterfeit formulations

\begin{tabular}{|c|c|c|}
\hline Anorectic & Legal status & Reference(s) \\
\hline Sibutramine & $\begin{array}{l}\text { Banned and withdrawn from markets due to the risk of } \\
\text { major cardiac events }\end{array}$ & {$[125-127]$} \\
\hline Fenfluramine & $\begin{array}{l}\text { Removed from the market by the manufacturer due to } \\
\text { association with serious health problems }\end{array}$ & [142] \\
\hline Phentermine & $\begin{array}{l}\text { Schedule IV in the US, available by prescription only } \\
\text { in many countries }\end{array}$ & {$[132]$} \\
\hline Metformin & Available by prescription only in many countries & {$[143]$} \\
\hline Buformin & $\begin{array}{l}\text { Never approved for sale in the US, removed from mar- } \\
\text { kets in most countries due to increased risk of lactic } \\
\text { acidosis. Available by prescription only in Romania }{ }^{1} \text {, } \\
\text { Hungary }^{2} \text {, Taiwan }{ }^{3} \text { and Japan }{ }^{4}\end{array}$ & {$[144,145]^{1},[146]^{2},[147]^{3},[147]^{4}$} \\
\hline Phenformin & $\begin{array}{l}\text { Withdrawn from the market as an antidiabetic drug due } \\
\text { to the high risk of fatal lactic acidosis }\end{array}$ & {$[148]$} \\
\hline Rimonabant & $\begin{array}{l}\text { Never approved in the US, withdrawn from the market } \\
\text { globally due to concerns over dangerous psychologi- } \\
\text { cal side effects, including suicidality and depression }\end{array}$ & {$[101,133]$} \\
\hline Amfepramone (diethylpropion) & $\begin{array}{l}\text { Classified as Schedule IV controlled substance in the } \\
\text { US and Canada }{ }^{1} \text {, Class C drug in the } \mathrm{UK}^{2} \text {, and avail- } \\
\text { able by prescription only in Australia }{ }^{3} \text { and Germany }{ }^{4}\end{array}$ & {$[149]^{1},[150]^{2},[151]^{3},[152]^{4}$} \\
\hline Methylphenidate & $\begin{array}{l}\text { Designated Schedule II internationally }{ }^{1} \text {, the } \\
\text { US }^{2}, \text { Schedule III in Canada }{ }^{3} \text { and Schedule } 8 \text { in } \\
\text { Australia }{ }^{4} \text {. Controlled substance Class B in the UK }{ }^{5} \text {, } \\
\text { Class B2 in New Zealand }{ }^{6} \text {, List II controlled sub- } \\
\text { stance of medical value in Sweden }{ }^{7} \text {, and controlled } \\
\text { Psychotropics in Japan }\end{array}$ & $\begin{array}{l}{[153]^{1},[154]^{2},[155]^{3},[156]^{4},[157]^{5},[158]^{6},[159]^{7},} \\
\quad[160]^{8}\end{array}$ \\
\hline Modafinil & $\begin{array}{l}\text { Classified as Schedule IV controlled substance in the } \\
\text { US }^{1} \text { and Sweden }{ }^{2} \text {, Schedule } 4 \text { prescription-only } \\
\text { medicine in Australia }{ }^{3} \text {, Class I and Schedule } 1 \\
\text { psychotropic drug in China }{ }^{4} \text { and Japan }{ }^{5} \text {, respectively, } \\
\text { and Schedule II controlled substance in the same } \\
\text { class as morphine and cocaine in Russia }\end{array}$ & {$[149]^{1},[161]^{2},[162]^{3},[163]^{4}[160]^{5},[164]^{6}$} \\
\hline Mitragynine (plant / alkaloids) & $\begin{array}{l}\text { Not listed under any schedules of the UNDC } \mathrm{UN}^{1} \text {; not } \\
\text { approved for any medical use and under Schedule } \\
\text { I consideration in the US } \mathrm{US}^{2} \text {, controlled as Narcotic } \\
\text { in Australia }{ }^{3} \text { and New Zealand }{ }^{4} \text {; controlled as } \\
\text { Designated substance in Japan }{ }^{5} \text {. Plant controlled in } \\
\text { Europe }^{6} \text { and prohibited in the } \mathrm{UK}^{7}\end{array}$ & {$[134]^{1},[165]^{2},[162]^{3},[166]^{4},[167]^{5},[110]^{6},[168]^{7}$} \\
\hline
\end{tabular}

but containing potentially harmful undeclared active ingredients, gives insight to the need for robust detection of counterfeit anorectics. The eleven-year data, presented in Fig. 2a, shows an extensive number of adulterated anorectics on the market (total 197), with an average of 18 adulterated new products per year. Multiple drug classes of banned and legal (prescription only) anorectics were deceptively hidden in these products. Predominantly, either sibutramine or its analogues only $(59 \%)$ or in combination with other drug classes $(84 \%)$ are found as undeclared chemicals in OTC slimming products (Fig. 2c). Most of these fake slimming medicines are developed for oral administration, commonly as capsules (Fig. 2b).

Due to the broad range of synthetic pharmaceutical classes that may be found as adulterants in slimming formulations, selectivity and sensitivity form the essential analytical requirements that must be fulfilled. Determination of chemical constituents of a suspected fake formulation, therefore, requires the vital initial step of sample preparation (extraction) and preconcentration using various techniques.

\section{Sample preparation for anorectics in counterfeit pharmaceuticals}

Despite the major advancements and production of powerful analytical instruments (e.g., sensors, microscopy, chromatography, spectroscopy), direct sample analyses, especially in biological and pharmaceutical formulations samples are often not possible owing to factors, such as matrix interference and low analyte concentrations [169]. This necessitates the use of some pretreatment steps aimed at sample 

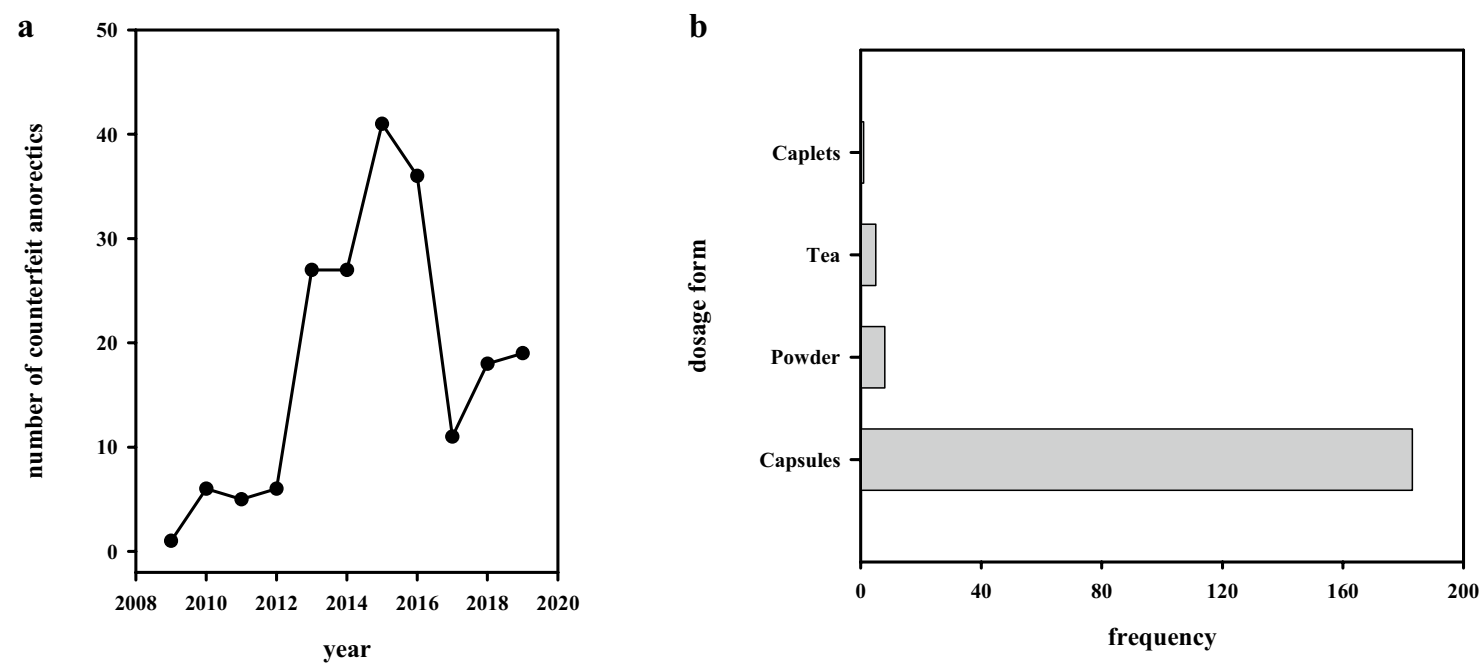

c



\author{
ש 1. Sibutramine/analogs \\ $\square 2$. Sibutramine/analogs and phenolphthale in \\ घ. Sibutramine/analogs and fluoxetine \\ -4. Sibutramine/analogs and other anorectics \\ $\square 5$. Other combinations (no sibutramine) \\ ๑. DMMA \\ $\square 7$. Phenolphthalein \\ $\square 8$. Fluoxetine \\ $\square 9$. Fluoxetine and phenolphthalein \\ $\square$ 10. Lorcaserin \\ $\square 11$. Lovastatin
}

Fig. 2 Counterfeit over-the-counter (OTC) weight loss products reported in the US following FDA laboratory analysis. a Tainted anorectics reported in the US from April 2009 to December 2019. b Distribution of common dosage forms of OTC weight loss products

cleanup, enrichment, as well as signal enhancement. Notable (but not exhaustive) pretreatment methods that have found application in preconcentration and cleanup of analytes prior to instrumental analysis in forensic investigations include: filtration with polyvinylidene difluoride membrane syringe [26, 27, 103], polytetrafluoroethylene [24] or cellulose acetate [170] filter following sample dissolution in organic solvent and sonication; solid-phase extraction (SPE) [171]; liquid-liquid extraction (LLE) [28], microwaveassisted extraction (MAE) [172], liquid-phase microextraction (LPME) [173, 174] and solid-phase micro-extraction (SPME) [175]. in the US. c Undeclared pharmaceutically active ingredients detected in OTC weight loss products in the US [see supplementary material, Table S1]. DMMA 3,4-dimethoxy- $N$ - methylamphetamine

Sporkert and Pragst [176] used headspace SPME (HSSPME) to extract amfepramone and other organic compounds. HS-SPME offers enhanced purification for complex biological samples, ensures green chemistry by avoiding organic solvent use and efficiently couple with gas chromatographic systems. Notwithstanding, the recoveries achieved by the HS-SPME pre-concentration technique were unsatisfactory. Other extraction methods also suffer significant limitations. SPE, especially, suffers analytic breakthrough when a large volume of samples is analysed [177]. Though being relatively simple, miniaturised and fast, LPME and SPME techniques are constrained with sample carry-over, 
relatively high cost, the fragility of the fibre and relatively low accuracy $[178,179]$. Given these limitations, developing new techniques with improved speed, safety, sensitivity, and reliability is of significant analytical interest. There is currently no consensus on a specific extraction/pre-concentration method for anorectic sample preparation. The different methods available in literature reflect the complexity of such counterfeited formulations and the target analytes.

\section{Analytical methods for determination of counterfeit anorectics}

Undeclared chemicals in slimming products or bodily fluids (such as blood or urine following exposure) can be analytically determined using several conventional methods. The most significant detection, identification and quantification of the parent drugs, analogues and/or metabolites are, however, achieved utilising the established techniques of liquid chromatography (LC) and gas chromatography (GC) coupled with mass spectrometry (MS) and spectroscopic methods. Table 2 shows cases of weight loss formulation use, analytical determination techniques and clinical outcomes.

\section{Liquid chromatography-mass spectrometry}

Liquid chromatography, coupled with mass spectrometry detection (LC-MS) has emerged as the preferred technique for identification and quantification of chemical entities in counterfeit and illegal pharmaceutical preparations [27, 180]. Considering the analytical gold standard, the LC-MS has been extensively utilized due to the high separation power that facilitates application to complex mixtures, enhanced sensitivity and specificity without the need for derivatization, and it is currently a well-established presence in most laboratories worldwide for routine analyses. Following separation via LC, the MS primarily enables conversion of analyte molecules to an ionized state, separating charged molecules according to their mass-to-charge ratio $(\mathrm{m} / \mathrm{z}$ value $)$ and subsequent identification as the charged species [181]. The foregoing thus enables targeted and untargeted screening of formulations, and in some instances, identification and/or structural elucidation of constituents of an unknown compound, when LC-MS is linked with infrared (IR) and nuclear magnetic resonance spectroscopy techniques [182].

Ultra-performance liquid chromatography (UPLC) provides a meaningful improvement over conventional LC and is especially useful for method development [170], where quick run times, including rapid response to alterations in column and mobile-phase conditions, are required. When linked to MS, UPLC is time-saving, offering improved performance in resolution, sensitivity and precision [183, 184]. Stypulkowska et al. [185] utilized LC-MS to determine the sibutramine and its analogues in some herbal dietary supplements. Similarly, undeclared rimonabant, sibutramine and their respective analogues were identified in imitated Acomplia [103]. In a survey of twenty-two herbal slimming preparations, Wang et al. [34] developed an LC-MS method which facilitated the simultaneous determination of sibutramine (45.5\%), $N$-monodesmethyl sibutramine $(9.1 \%)$ and phenolphthalein (13.6\%) in the samples analysed.

Liquid chromatography with tandem mass spectrometry (LC-MS/MS) has been applied for analytical profiling of counterfeit pharmaceuticals in recent years. By coupling LC and two MS connected in series, the method allows sample separation, ionization and characterization utilizing the $m / z$ value and relative abundance [186]. Subsequently, LC-MS/MS enables analysis of complex matrices with optimum molecular specificity and detection sensitivity that allow structural identification of each constituent of the mixture [187]. Kim et al. [188] developed and validated an LC-MS/MS method for routine herbal dietary supplement adulteration screening for sibutramine and its metabolites. An LC-MS/MS method with the ability to screen synthetic adulterants from multiple pharmacological classes including anorectics (e.g., fenfluramine, methylphenidate, sibutramine) in herbal remedies was also developed by Bogusz et al. [189]. A similar technique applying LC-QTRAP-MS/ MS was used by Chen et al. [190] to determine blood pressure and lipid-lowering agents, sedative drugs, antidiabetic drugs, weight-reducing agents and aphrodisiac compounds, in adulterated plant-based health supplements. Other analytical approaches to the analysis of counterfeited slimming phytotherapeutic formulations have been comprehensively reviewed by De Carvalho et al. [25].

\section{Gas chromatography-mass spectrometry}

The GC method has been used in the detection and characterization of counterfeit medicines. When combined with mass spectrometry, GC-MS primary use lies with the analysis of illegal pharmaceutical formulations in medicine control laboratories [32]. For example, GC-MS was utilized to determine anorectics, stimulants and benzodiazepines in counterfeit slimming drugs $[32,112]$. Due to the nonvolatile and considerable hydrophilic nature of most pharmaceutical formulations, complex derivatization to their respective less polar compounds is often necessary to enhance their identification and quantitative analysis [169]. GC-tandem MS (GC-MS/MS) offers enhanced separation, higher precision and selectivity, and has been employed in profiling some anorectics in fake pharmaceuticals. Li et al. [191] developed a GC-electron ionization-MS/MS method to simultaneously detect seven adulterants, including the anorectics fenfluramine, amfepramone and sibutramine in slimming functional foods. In a recent study, and the first proof of concept, 


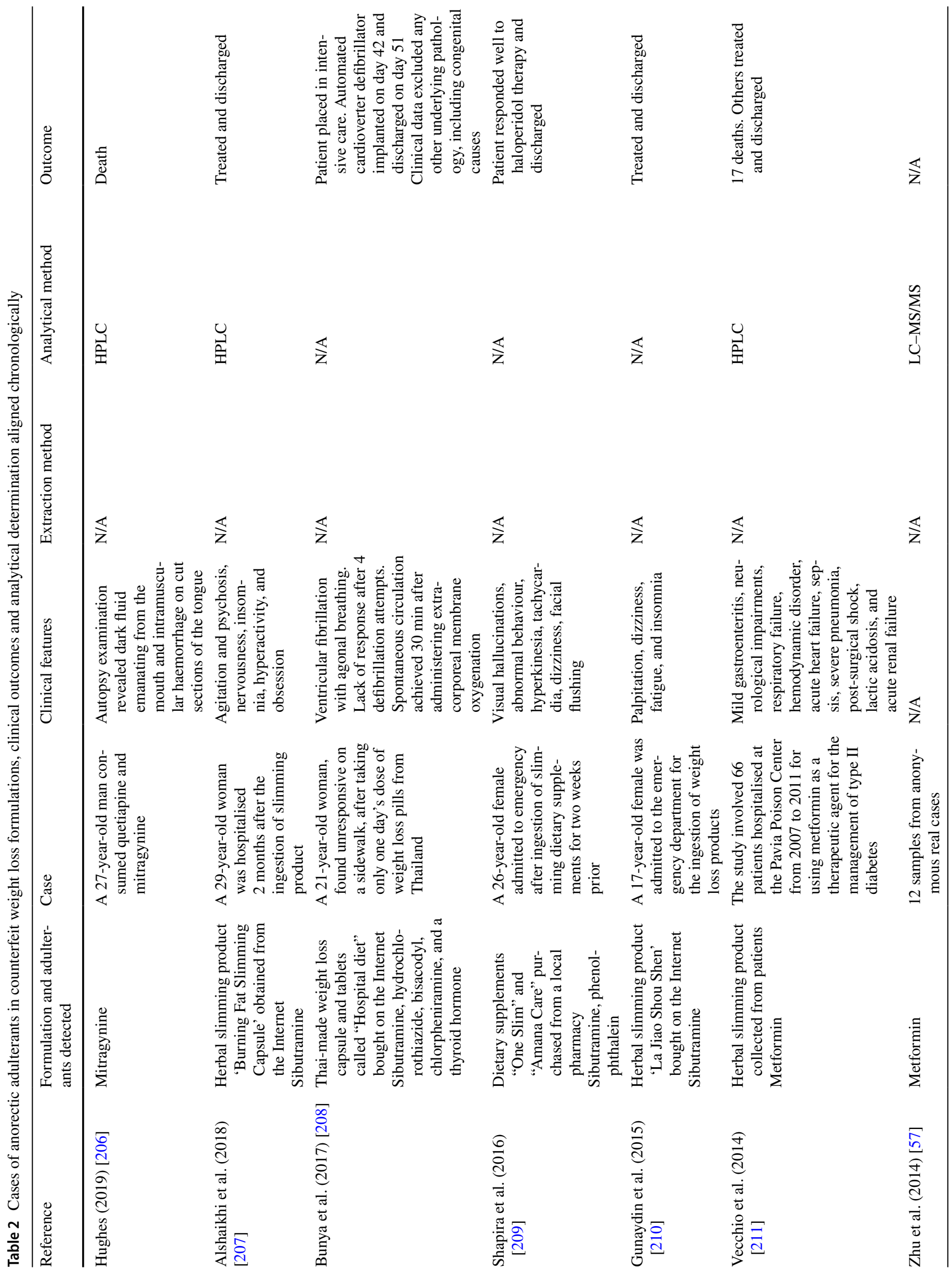









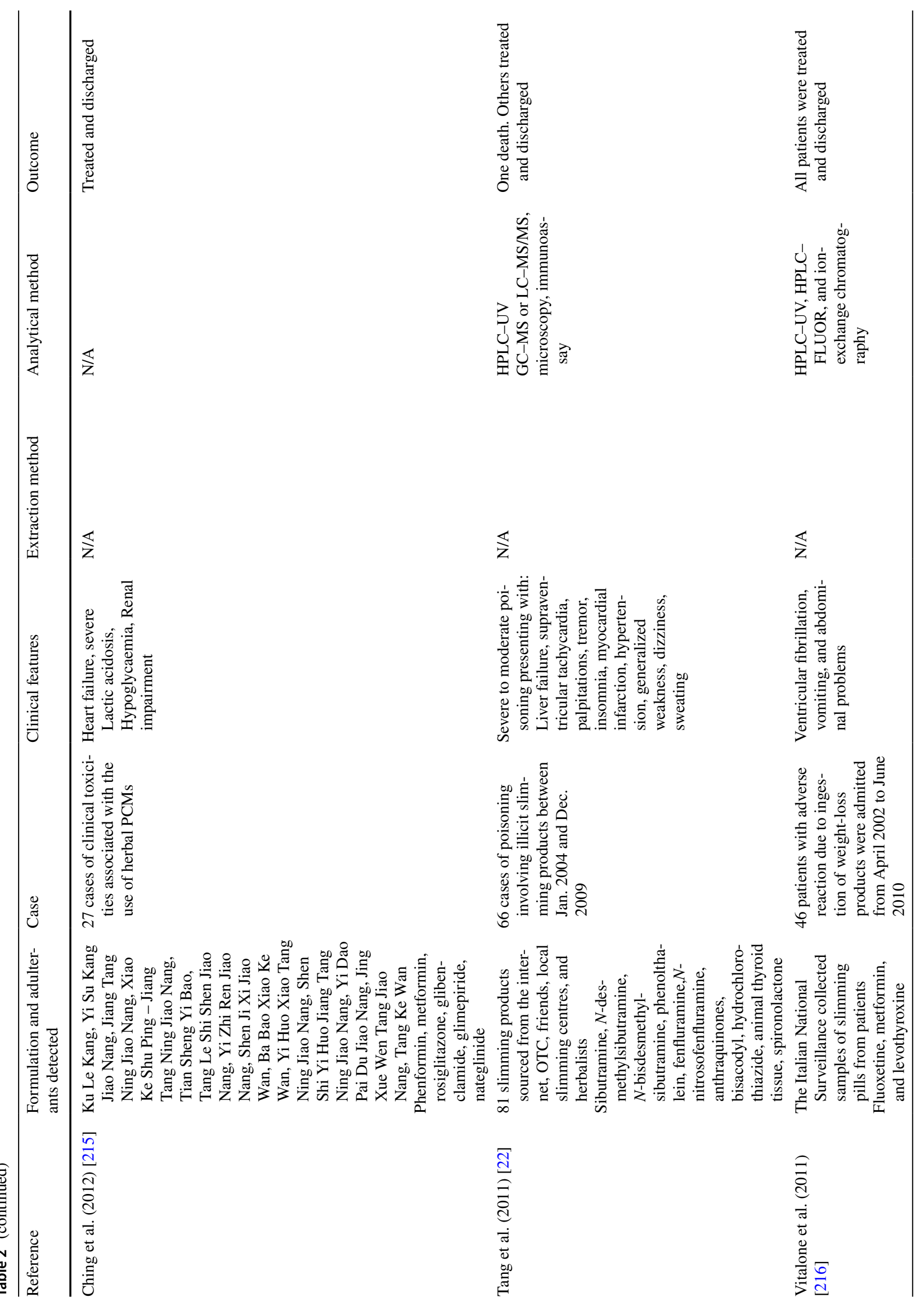



















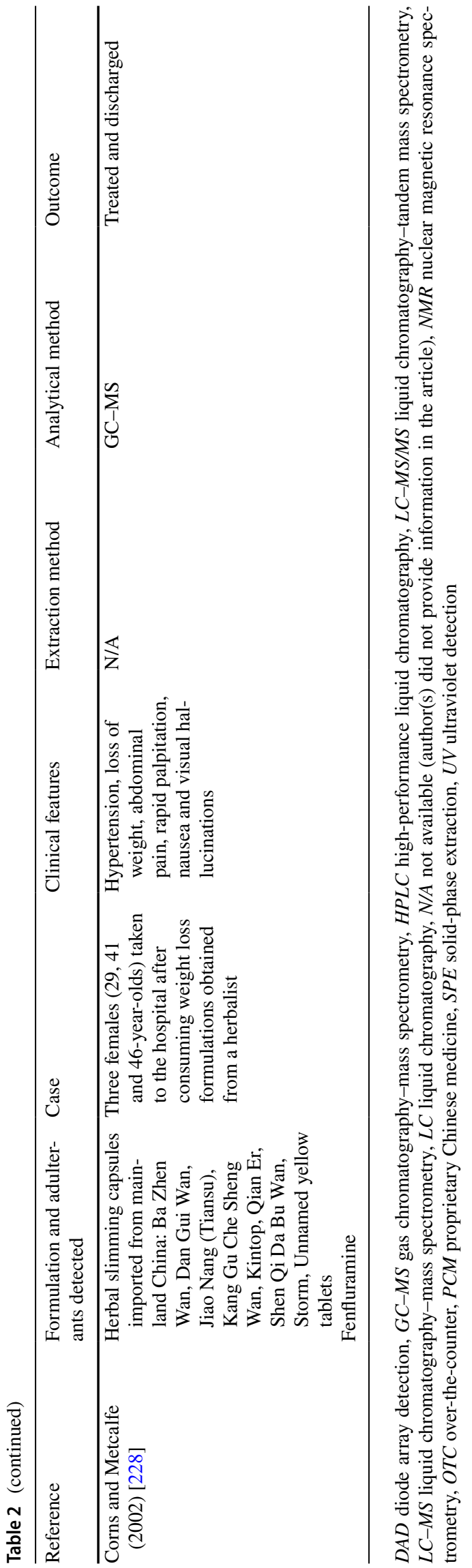

Arbouche et al. [192] developed a GC-MS/MS method to determine metformin in human hair following prolonged use of the antidiabetic drug. The sensitive technique showed limits of detection and quantification at 1 and $100 \mathrm{pg} / \mathrm{mg}$ hair, respectively, but illustrated the poor incorporation of metformin into human hair in comparison with other drugs.

Derivatization for GC-MS analysis depends on the chemical properties of specific anorectics. For example, pentafluoropropionic anhydride derivatization was employed for simultaneous screening of fenfluramine and phentermine in urine samples [142]. Similarly, Strano-Rossi et al. [169] detected metabolites of sibutramine in a study of its pattern of fragmentation following derivatization to the corresponding methyl and trimethylsilyl derivatives. Arbouche et al. [192] and Goedecke et al. [193] used acylation reagent, $\mathrm{N}$-methyl-bis(trifluoroacetamide) (MBTFA) derivatization and GC-MS to determine the metformin in hair and surface water, respectively. A similar GC-MS approach, in combination with LC-diode array detection, was used by Liu et al. [194] to screen anorectics and other adulterants in 266 phytotherapeutic formulations. Unlike LC-MS, the derivatization requirement of GC-MS analysis makes the analytical procedure cumbersome and error-prone [195]. Current trends in analytical method development and validation are aimed at advancing simplicity and reducing time at each analytical stage while increasing analytical throughput. The need to often change solvents increases complexity and extends sample preparation times. This makes GC-MS analysis process of counterfeit formulations inconsistent with current trends, despite its merits. However, the costs for $\mathrm{GC}-\mathrm{MS}$ or $\mathrm{GC}-\mathrm{MS} / \mathrm{MS}$ instruments are relatively lower than those LC-MS/MS instruments at this time.

\section{Capillary electrophoresis}

Capillary electrophoresis (CE) has become a versatile separation technique in contemporary biopharmaceutical analytics, albeit in a considerably smaller footprint as compared to GC and LC. Sample pre-concentration for CE allows for short analysis times, reduced volumes of the sample and reagents used, and high selectivity [196]. Two forms of CE, micellar electrokinetic chromatography [197] and capillary zone electrophoresis (CZE) [198] have been used as affordable alternatives for counterfeit pharmaceutical determination. Piette and Parmentier [199] utilised CZE to analyse amphetamine-based anorectics in seized formulations. While the conventional CE technique generally employs UV detectors, hyphenation with MS detectors for highly resolved chemical and structural information of adulterants of weight loss pills and dietary supplements have been investigated as a potential confirmatory approach. Akamatsu and Mitsuhasi [200] and dos Santos et al. [201] developed CE-MS/MS methods to identify anorectics and other adulterants in some 
phytotherapeutics, yielding limits of detections lower than $0.06 \mu \mathrm{g} \mathrm{L}^{-1}$. As compared to LC, CE equipment and accessories are cheaper, lasts longer, simple to use and requires minimal amounts of reagents and samples [202]. Further method development and validations are envisaged to offer $\mathrm{CE}$ as a robust option in fighting counterfeit drugs especially in developing countries.

\section{Nanomaterials}

Nanotechnology is a powerful tool that has demonstrated its usefulness in many fields, although more work needs still to be done to transfer the results from research to routine analysis. Nanomaterials are used in the dietary supplement industry to improve the drug delivery to target organs, tissues or cells. The methods used for the determination of nanomaterials in dietary supplements have been reviewed, finding that $\mathrm{CE}$ is the technique of choice to determine different metal nanoparticles, such as gold, platinum or palladium [203].

The second use of nanomaterials deals with their use in the proposal of new analytical methods for the determination of anorectics, although it is still in the incipient stage. Sample preparation is one of the most challenging steps since most errors in the analytical process arise from this step. Carbon nanotubes (CNTs) have been used to determine metformin [204] and amphetamine-derived anorectics, including phentermine [205].

Magnetic multi-walled CNTs were used to produce a methacrylate-based molecularly imprinted polymer on their surface, where metformin was used as the template [204]. Some advantages of this polymer are the faster kinetics of sorption and desorption owing to the high surface area of nanomaterials, as well as the ease of operation owing to the magnetic properties of the nanomaterial that facilitates its separation from complex matrices during the extraction process. The method was applied to different spiked samples, such as urine, human serum, and sea, tap and mineral water, with extraction recovery percentages in the range of 95.5-104.7\%. Oxidized multi-walled CNTs have been used to coat SPME fibres for the microextraction of 7 amphetamine-like stimulants in urine [205]. The oxidation of CNTs allows a higher surface area compared to bare CNTs, as well as the introduction of hydroxyl groups owing to the oxidation process enhances the interaction with polar analytes.

The use of nanomaterials for the detection of anorectics has been more extensively used than for sample preparation. Although gold-based nanomaterials have been used for the determination of metformin alone [229] or in binary mixtures [230] and fenfluramine [231], the most important contribution of nanomaterials to anorectic determination is their integration into electrochemical sensors [232-234]. Several sensors have been described for metformin determination, as amperometric sensors, using graphene/nanoflakes-polymethylene blue/fluorine doped tin oxide, nickel oxide nanotubes, nanostructured $\mathrm{Fe}-\mathrm{Cu} / \mathrm{TiO}_{2}$, a $\mathrm{Cu}$ metal-organic framework to modify surface of different electrodes [232], as well as zinc ferrite, copper oxide and gold nanoparticles have been successfully used to modify the surface of a glassy carbon electrode [233]. Impedimetric sensors have also been developed using nanomaterials, such as Prussian Blue nanocubes/ carbon nanospheres/fluorine doped tin oxide. The excellent features of nanomaterials, such as high surface-to-volume ratio and high conductivity, have provided high sensitivity and selectivity levels to the developed sensors. Screenprinted electrodes have been integrated with CNTs to detect modafinil in saliva by adsorptive stripping voltammetry [234]. This constitutes one example on integrated analytical platform using nanomaterials and printing technologies, where CNTs are used as SPE sorbents prior to adsorptive stripping voltammetry. The integration of SPE and the printed electrochemical sensor constitutes a real advantage and ease the operation of the electrochemical sensor when the analysis of real samples is tackled.

\section{Conclusions}

Slimming formulations doped with anorectic cocktails to boost their weight-reducing effectiveness are not uncommon and present a global health and safety threat. The effects of such additives, often from multiple chemical classes on the human body, are unpredictable. This review has highlighted the current scope of anorectics generally found as adulterants in weight-reducing formulations, including their mode of action and adverse effects on unsuspecting users. The limitations and mitigation strategies of conventional sample preparation / instrumental analyses have also been presented. While LC-MS(/MS) remains the gold standard for analytical profiling of such counterfeits, improved pre-concentration methods are required to facilitate rapid and quantitative identification of specific chemical constituents. Also, CE presents an essential alternative to $\mathrm{LC}$ and GC due to much lower cost in fighting anorectic adulteration in pharmaceutical formulations. The incipient use of nanomaterials has opened new insights in sensor development as a powerful tool to screen for samples before proceeding to confirmatory analysis by LC-MS, GC-MS and CE. This summary of available literature also provides insight into the present state of research in profiling adulterants in counterfeit anorectic products.

Acknowledgements Dan O. M. Bonsu was financially supported by the Education, Audiovisual and Culture Executive Agency (EACEA) of the European Union for his Erasmus Mundus MSc Forensic Science study at the University of Lincoln, United Kingdom, University of Cordoba, Spain and Instituto Superior de Ciências da Saúde Egas Moniz, 
Portugal. M. P. Aguilar-Caballos gratefully acknowledges the financial support from Operative Framework Funding FEDER-Andalucía 20142020 Program (Ref. UCO-1263679).

\section{Compliance with ethical standards}

Conflict of interest There are no financial or other relations that could lead to a conflict of interest.

Ethical approval This article does not contain any studies with human participants or animals performed by any of the authors.

Open Access This article is licensed under a Creative Commons Attribution 4.0 International License, which permits use, sharing, adaptation, distribution and reproduction in any medium or format, as long as you give appropriate credit to the original author(s) and the source, provide a link to the Creative Commons licence, and indicate if changes were made. The images or other third party material in this article are included in the article's Creative Commons licence, unless indicated otherwise in a credit line to the material. If material is not included in the article's Creative Commons licence and your intended use is not permitted by statutory regulation or exceeds the permitted use, you will need to obtain permission directly from the copyright holder. To view a copy of this licence, visit http://creativecommons.org/licenses/by/4.0/.

\section{References}

1. Cabezas M-D (2010) Counterfeit medicines as global treat. Pharm Policy Law 12:179-192. https://doi.org/10.3233/ PPL-2010-0304

2. Jackson G, Patel S, Khan S (2012) Assessing the problem of counterfeit medications in the United Kingdom. Int J Clin Pract 66:241-250. https://doi.org/10.1111/j.1742-1241.2011.02826.x

3. Deisingh A-K (2005) Pharmaceutical counterfeiting. Analyst 130:271-279. https://doi.org/10.1039/b407759h

4. Europharm Forum (2009) Framework for a guide on counterfeit medicines for pharmacists. shorturl.at/divFN. Accessed $15 \mathrm{Jul}$ 2020

5. Pharmaceutical Security Institute (PSI) (2019) Pharma crime: geographic distribution. https://www.psi-inc.org/geographic-distr ibution. Accessed 1 Jun 2020

6. Dégardin K, Roggo Y, Margot P (2015) Forensic intelligence for medicine anti-counterfeiting. Forensic Sci Int 248:15-32. https ://doi.org/10.1016/j.forsciint.2014.11.015

7. Medicines and Healthcare products Regulatory Agency (2018) UK seizes more than $£ 2$ million of fake medicines as part of international crackdown. https://www.gov.uk/government/news/ uk-seizes-more-than-2-million-of-fake-medicines-as-part-ofinternational-crackdown. Accessed 1 Jun 2020

8. Interpol (2019) Operation Pangea—shining a light on pharmaceutical crime. https://www.interpol.int/en/News-and-Events/ News/2019/Operation-Pangea-shining-a-light-on-pharmaceut ical-crime. Accessed 1 Jun 2020

9. UNODC (2019) What we have learned over the last ten years: a summary of knowledge acquired and produced by the UN system on drug-related matters. https://www.unodc.org/docum ents/commissions/CND/2019/Contributions/UN_Entities/ What_we_have_learned_over_the_last_ten_years_-_14_March _2019_-_w_signature.pdf. Accessed 1 Jun 2020

10. Acri K (2018) They cost us billions and they can kill: counterfeit drugs are invading Canada. In: Financ. Post. https:// business.financialpost.com/opinion/they-cost-us-billions-andthey-can-kill-counterfeit-drugs-are-invading-canada. Accessed 1 Jun 2020

11. Acri KML, Lybecker N (2018) Pharmaceutical counterfeiting: endangering public health, society and the economy. In: Fraser Inst. https://www.fraserinstitute.org/sites/default/files/pharm aceutical-counterfeiting-endangering-public-health-societyand-the-economy.pdf. Accessed 1 Jun 2020

12. Swissmedic (2013) Over $400 \mathrm{~kg}$ of fake anxiolytic seized at Zurich airport. React Wkly 1475:3. https://doi.org/10.1007/ s40278-013-6698-2

13. Kelesidis T, Kelesidis I, Rafailidis PI, Falagas ME (2007) Counterfeit or substandard antimicrobial drugs: a review of the scientific evidence. J Antimicrob Chemother 60:214-236. https://doi.org/10.1093/jac/dkm109

14. Gaudiano M-C, Di Maggio A, Antoniella E, Valvo L, Bertocchi P, Manna L, Bartolomei M, Alimonti S, Rodomonte A-L (2008) An LC method for the simultaneous screening of some common counterfeit and sub-standard antibiotics: validation and uncertainty estimation. J Pharm Biomed Anal 48:303-309. https://doi.org/10.1016/j.jpba.2007.12.032

15. Delepierre A, Gayot A, Carpentier A (2012) Update on counterfeit antibiotics worldwide; public health risks. Med Mal Infect 42:247-255. https://doi.org/10.1016/j.medma 1.2012.04.007

16. Newton PN, Amin AA, Bird C, Passmore P, Dukes G, Tomson G, Simons B, Bate R, Guerin PJ, White NJ (2011) The primacy of public health considerations in defining poor quality medicines. PLoS Med 8:e1001139. https://doi.org/10.1371/journ al.pmed.1001139

17. Newton PN, White NJ, Rozandaal JA, Green MD (2002) Murder by fake drugs: time for international action. BMJ 324:800-801. https://doi.org/10.1136/bmj.324.7341.800

18. Sacré P-Y, Deconinck E, Chiap P, Crommen J, Mansion F, Rozet E, Courselle P, De Beer J-O (2011) Development and validation of a ultra-high-performance liquid chromatography-UV method for the detection and quantification of erectile dysfunction drugs and some of their analogues found in counterfeit medicines. J Chromatogr A 1218:6439-6447. https://doi.org/10.1016/j.chrom a.2011.07.029

19. Tero-Vescan A, Vari C-E, Filip C, Ősz B-E, Ceană D, Imre S, Hancu G (2014) Analysis of dietary supplements and drugs forerectile dysfunction by HPLC-UV. Acta Medica Transilvanica 2:297-299

20. de Carvalho LM, Correia D, Garcia SC, de Bairros AV, do Nascimento PC, Bohrer D (2010) A new method for the simultaneous determination of 1,4-benzodiazepines and amfepramone as adulterants in phytotherapeutic formulations by voltammetry. Forensic Sci Int 202:75-81. https://doi.org/10.1016/j.forsc iint.2010.04.030

21. Parodi B, Caviglioli G, Bachi A, Cafaggi S, Romussi G (1993) Herbal mixtures with claimed slimming activity: determination by TLC and HPLC of illegally added drugs. Pharmazie 48:678681 (PMID:8234401)

22. Tang MHY, Chen SPL, Ng SW, Chan AYW, Mak TWL (2011) Case series on a diversity of illicit weight-reducing agents: from the well known to the unexpected. Br J Clin Pharmacol 71:250 253. https://doi.org/10.1111/j.1365-2125.2010.03822.x

23. Dégardin K, Roggo Y, Margot P (2014) Understanding and fighting the medicine counterfeit market. J Pharm Biomed Anal 87:167-175. https://doi.org/10.1016/j.jpba.2013.01.009

24. Ariburnu E, Uludag MF, Yalcinkaya H, Yesilada E (2012) Comparative determination of sibutramine as an adulterant in natural slimming products by HPLC and HPTLC densitometry. J Pharm Biomed Anal 64-65:77-81. https://doi.org/10.1016/j. jpba.2012.02.004 
25. de Carvalho LM, Martini M, Moreira APL, de Lima APS, Correia D, Falcão T, Garcia SC, de Bairros AV, do Nascimento PC, Bohrer D, (2011) Presence of synthetic pharmaceuticals as adulterants in slimming phytotherapeutic formulations and their analytical determination. Forensic Sci Int 204:6-12. https ://doi.org/10.1016/j.forsciint.2010.04.045

26. Kim JW, Kweon SJ, Park SK, Kim JY, Lee JH, Han KM, Cho S, Kim J, Han SY, Kim HJ, Kim WS (2013) Isolation and identification of a sibutramine analogue adulterated in slimming dietary supplements. Food Addit Contam Part A 30:12211229. https://doi.org/10.1080/19440049.2013.793826

27. Lee JH, Kim NS, Han KM, Kim SH, Cho S, Kim WS (2013) Monitoring by LC-MS/MS of 48 compounds of sildenafil, tadalafil, vardenafil and their analogues in illicit health food products in the Korean market advertised as enhancing male sexual performance. Food Addit Contam Part A 30:1849-1857. https://doi.org/10.1080/19440049.2013.826878

28. Um SY, Kim KB, Kim SH, Ju YC, Lee HS, Oh HY, Choi KH, Chung MW (2008) Determination of the active metabolites of sibutramine in rat serum using column-switching HPLC. J Sep Sci 31:2820-2826. https://doi.org/10.1002/jssc.200800041

29. Yuen YP, Lai CK, Poon WT, Ng SW, Chan AYW, Mak TWL (2007) Adulteration of over-the-counter slimming products with pharmaceutical analogue - an emerging threat. Hong Kong Med J 13:216-220 (open access article)

30. Al-Safi SA, Ayoub NM, Ayoub AM, Al-Momany E, Al-Doghim I, Al-Balas M, Alkofahi AS, Aboul-Enein FH, Aboul-Enein BH (2008) Public awareness of the abuse of herbs and drugs to decrease body weight: a novel national survey in Jordan. J Public Health 16:205-213. https://doi.org/10.1007/s10389-007-0166-5

31. Kesting JR, Huang J, Sørensen D (2010) Identification of adulterants in a Chinese herbal medicine by LC-HRMS and LC-MSSPE/NMR and comparative in vivo study with standards in a hypertensive rat model. J Pharm Biomed Anal 51:705-711. https ://doi.org/10.1016/j.jpba.2009.09.043

32. Khazan M, Hedayati M, Kobarfard F, Askari S, Azizi F (2014) Identification and determination of synthetic pharmaceuticals as adulterants in eight common herbal weight loss supplements. Iran Red Crescent Med J 16:e15344. https://doi.org/10.5812/ ircmj. 15344

33. Sombra LL, Gómez MR, Olsina R, Martínez LD, Silva MF (2005) Comparative study between capillary electrophoresis and high performance liquid chromatography in 'guarana' based phytopharmaceuticals. J Pharm Biomed Anal 36:989-994. https ://doi.org/10.1016/j.jpba.2004.08.026

34. Wang J, Chen B, Yao S (2008) Analysis of six synthetic adulterants in herbal weight-reducing dietary supplements by LC electrospray ionization-MS. Food Addit Contam Part A 25:822-830. https://doi.org/10.1080/02652030801946553

35. Yano HM, Farias FF, Del Bianco MB, Trujillo LM (2013) Determination of the sibutramine content of dietary supplements using LC-ESI-MS/MS. Lat Am J Pharm 32:1164-1169 (open access article)

36. Hobold E, de Arruda M (2015) Prevalence of overweight and obesity in schoolchildren: relationship with socioeconomic status, gender and age. Rev Bras Cineantropom e Desempenho Hum 17:156-164. https://doi.org/10.5007/1980-0037.2015v17n2p156

37. Swinburn BA, Sacks G, Hall KD, McPherson K, Finegood DT, Moodie ML, Gortmaker SL (2011) The global obesity pandemic: shaped by global drivers and local environments. Lancet 378:804-814. https://doi.org/10.1016/S0140-6736(11)60813-1

38. Bray GA (2013) Why do we need drugs to treat the patient with obesity? Obesity 21:893-899. https://doi.org/10.1002/oby.20394

39. Almuzaini T, Choonara I, Sammons H (2012) A systematic review of counterfeit and substandard medicines. Arch Dis Child
97(Suppl 1):A1-A2. https://doi.org/10.1136/archdischild-2012301885.3

40. Fincham JE (2014) Counterfeit medications and their negative impacts on health care. Am J Pharm Educ 78:48. https://doi. org/10.5688/ajpe78348

41. Filippatos TD, Kiortsis DN, Liberopoulos EN, Mikhailidis DP, Elisaf MS (2005) A review of the metabolic effects of sibutramine. Curr Med Res Opin 21:457-468. https://doi. org/10.1185/030079905X38132

42. Sánchez-Reyes L, Fanghänel G, Yamamoto J, Martínez-Rivas NL, Campos-Franco E, Berber A (2004) Use of sibutramine in overweight adult hispanic patients with type 2 diabetes mellitus: a 12-month, randomized, double-blind, placebo-controlled clinical trial. Clin Ther 26:1427-1435. https://doi.org/10.1016/j.clint hera.2004.09.017

43. Finer $N$ (2002) Sibutramine: its mode of action and efficacy. Int J Obes 26:S29-S33. https://doi.org/10.1038/sj.ijo.0802216

44. Sharma B, Henderson DC (2008) Sibutramine: current status as an anti-obesity drug and its future perspectives. Expert Opin Pharmacother 9:2161-2173. https://doi.org/10.1517/14656 566.9.12.2161

45. Astrup A (2000) Thermogenic drugs as a strategy for treatment of obesity. Endocrine 13:207-212. https://doi.org/10.1385/ ENDO: 13:2:207

46. Luque CA, Rey JA (2002) The discovery and status of sibutramine as an anti-obesity drug. Eur J Pharmacol 440:119128. https://doi.org/10.1016/S0014-2999(02)01423-1

47. Mancini MC, Halpern A (2006) Pharmacological treatment of obesity. Arq Bras Endocrinol Metab 50:377-389. https://doi. org/10.1590/S0004-27302006000200024

48. Seagle HM, Bessesen DH, Hill JO (1998) Effects of sibutramine on resting metabolic rate and weight loss in overweight women. Obes Res 6:115-121. https://doi.org/10.1002/j.1550-8528.1998. tb00324.x

49. Walsh KM, Leen E, Lean MEJ (1999) The effect of sibutramine on resting energy expenditure and adrenaline-induced thermogenesis in obese females. Int J Obes 23:1009-1015. https://doi. org/10.1038/sj.ijo.0801045

50. Chang K, Mak TWL, Kwong L, So KT (2005) Valvular heart disease caused by Chinese proprietary slimming medicine adulterated with fenfluramine. Hong Kong J Paediatr (New Series) 10:55-58. http://www.hkjpaed.org/pdf/2005;10;55-58.pdf (open access article)

51. Surapaneni P, Vinales KL, Najib MQ, Chaliki HP (2011) Valvular heart disease with the use of fenfluramine-phentermine. Texas Hear Inst J 38:581-583 (PMID:2216314)

52. Chen SPL, Tang MHY, Ng SW, Poon WT, Chan AYW, Mak TWL (2010) Psychosis associated with usage of herbal slimming products adulterated with sibutramine: a case series. Clin Toxicol 48:832-838. https://doi.org/10.3109/15563650.2010.517208

53. Rojas LBA, Gomes MB (2013) Metformin: an old but still the best treatment for type 2 diabetes. Diabetol Metab Syndr 5:6. https://doi.org/10.1186/1758-5996-5-6

54. Gong L, Goswami S, Giacomini KM, Altman RB, Klein TE (2012) Metformin pathways: pharmacokinetics and pharmacodynamics. Pharmacogenet Genomics 22:820-827. https://doi. org/10.1097/FPC.0b013e3283559b22

55. Graham GG, Punt J, Arora M, Day RO, Doogue MP, Duong JK, Furlong TJ, Greenfield JR, Greenup LC, Kirkpatrick CM, Ray JE, Timmins P, Williams KM (2011) Clinical pharmacokinetics of metformin. Clin Pharmacokinet 50:81-98. https://doi. org/10.2165/11534750-000000000-00000

56. Scheen AJ (1996) Clinical pharmacokinetics of metformin. Clin Pharmacokinet 30:359-371. https://doi.org/10.2165/00003088199630050-00003 
57. Zhu Q, Cao Y, Cao Y, Chai Y, Lu F (2014) Rapid on-site TLCSERS detection of four antidiabetes drugs used as adulterants in botanical dietary supplements. Anal Bioanal Chem 406:18771884. https://doi.org/10.1007/s00216-013-7605-7

58. FDA (2002) Metformin hydrochloride tablets. U.S. Food Drug Adm. http://www.fda.gov/ohrms/dockets/dailys/02/May02/05310 2/800471e6.pdf. Accessed 8 Jul 2015

59. van Ieperen I, Vermeij CG, van Belo-van de Laar IRF, Doorenbos CJ (2015) Hemodialysis versus continuous venovenous hemofiltration treatment of metformin associated lactic acidosis. Nephrol Dial Transplant 30(Suppl. 3):241. https://doi.org/10.1093/ndt/ gfv179.37

60. Weisberg LS (2015) Lactic acidosis in apatient with type 2 diabetes mellitus. Clin J Am Soc Nephrol 10:1476-1483. https:// doi.org/10.2215/CJN.10871014

61. Wolf C, Tanner M (2002) Obesity. West J Med 176:23-28. https ://doi.org/10.1136/ewjm.176.1.23

62. Uwaifo GI, Melcescu E, McDonald A, Koch CA (2009) A case of profound weight loss secondary to use of phentermine. J Miss State Med Assoc 50:407-415 (PMID:20806811)

63. Cosentino G, Conrad AD, Uwaifo GI (2013) Phentermine and topiramate for the management of obesity: a review. Drug Des Devel Ther 7:267-278. https://doi.org/10.2147/DDDT.S31443

64. Moldovan CP, Weldon AJ, Daher NS, Schneider LE, Bellinger DL, Berk LS, Hermé AC, Aréchiga AL, Davis WL, Peters WR (2016) Effects of a meal replacement system alone or in combination with phentermine on weight loss and food cravings. Obesity 24:2344-2350. https://doi.org/10.1002/oby.21649

65. Yanovski SZ, Yanovski JA (2014) Long-term drug treatment for obesity. JAMA 311:74-86. https://doi.org/10.1001/ jama.2013.281361

66. Bain JA, Dority JS, Cook AM (2014) Subarachnoid hemorrhage in a patient taking phentermine for weight loss. J Am Pharm Assoc 54:548-551. https://doi.org/10.1331/JAPhA.2014.13226

67. Hendricks EJ, Greenway FL (2011) A study of abrupt phentermine cessation in patients in a weight management program. Am J Ther 18:292-299. https://doi.org/10.1097/MJT.0b013e3181 d070d7

68. Aronne LJ, Halseth AE, Burns CM, Miller S, Shen LZ (2010) Enhanced weight loss following coadministration of pramlintide with sibutramine or phentermine in a multicenter trial. Obesity 18:1739-1746. https://doi.org/10.1038/oby.2009.478

69. Hendricks EJ, Rothman RB, Greenway FL (2009) How physician obesity specialists use drugs to treat obesity. Obesity 17:1730 1735. https://doi.org/10.1038/oby.2009.69

70. Bray GA, Greenway FL (2007) Pharmacological treatment of the overweight patient. Pharmacol Rev 59:151-184. https://doi. org/10.1124/pr.59.2.2

71. Roth JD, Trevaskis JL, Wilson J, Lei C, Athanacio J, Mack C, Kesty NC, Coffey T, Weyer C, Parkes DG (2008) Antiobesity effects of the $\beta$-cell hormone amylin in combination with phentermine or sibutramine in diet-induced obese rats. Int J Obes 32:1201-1210. https://doi.org/10.1038/ijo.2008.91

72. Rocha T, Amaral JS, Oliveira MBPP (2016) Adulteration of dietary supplements by the illegal addition of synthetic drugs: a review. Compr Rev Food Sci Food Saf 15:43-62. https://doi. org/10.1111/1541-4337.12173

73. Ahmed N, Nounou MI, Abouelfetouh A, El-Kamel A (2019) Over-the-counter herbal weight loss supplements in Egypt: label claim, microbiological and pharmaceutical quality, and safety assessments. Med Princ Pract 28:167-177. https://doi. org/10.1159/000495986

74. García-Alonso D, Morgenstern-Kaplan D, Cohen-Welch A, Lozano-Cuenca J, López-Canales JS (2019) Possible mechanisms involved in the vasorelaxant effect produced by anorexigenic drugs in rat aortic rings. Med Sci 7:39. https://doi. org/10.3390/medsci7030039

75. López-Canales JS, Lozano-Cuenca J, Muãoz-Islas E, AguilarCarrasco JC, López-Canales OA, López-Mayorga RM, CastilloHenkel EF, Valencia-Hernández I, Castillo-Henkel C (2015) Mechanisms involved in the vasorelaxant effects produced by the acute application of amfepramone in vitro to rat aortic rings. Brazil J Med Biol Res 48:537-544. https://doi.org/10.1590/1414$431 \times 20144261$

76. De Carvalho LM, Cohen PA, Silva CV, Moreira APL, Falcão TM, Dal Molin TR, Zemolin G, Martini M (2012) A new approach to determining pharmacologic adulteration of herbal weight loss products. Food Addit Contam Part A 29:1661-1667. https://doi.org/10.1080/19440049.2012.706834

77. Almeida AE, Ribeiro ML, Polese L (2000) Determination of amfepramone hydrochloride, fenproporex, and diazepam in so-called "natural" capsules used in the treatment of obesity. J Liq Chromatogr Relat Technol 23:1109-1118. https://doi. org/10.1081/JLC-100101512

78. Suplicy H, Boguszewski CL, Dos Santos CMC, do Desterro de Figueiredo M, Cunha DR, Radominski R (2014) A comparative study of five centrally acting drugs on the pharmacological treatment of obesity. Int J Obes 38:1097-1103. https://doi. org/10.1038/ijo.2013.225

79. Abramowicz MJ, Van Haecke P, Demedts M, Delcroix M (2003) Primary pulmonary hypertension after amfepramone (diethylpropion) with BMPR2 mutation. Eur Respir J 22:560-562. https:// doi.org/10.1183/09031936.03.00095303

80. Cercato C, Roizenblatt VA, Leança CC, Segal A, Lopes Filho AP, Mancini MC, Halpern A (2009) A randomized double-blind placebo-controlled study of the long-term efficacy and safety of diethylpropion in the treatment of obese subjects. Int J Obes 33:857-865. https://doi.org/10.1038/ijo.2009.124

81. Challman TD, Lipsky JJ (2000) Methylphenidate: its pharmacology and uses. Mayo Clin Proc 75:711-721. https://doi. org/10.4065/75.7.711

82. Volkow N-D, Fowler J-S, Wang G-J, Ding Y-S, Gatley S-J (2002) Mechanism of action of methylphenidate: insights from PET imaging studies. J Atten Disord 6:31-43. https://doi. org/10.1177/070674370200601s05

83. Scahill L, Carroll D, Burke K (2004) Methylphenidate: mechanism of action and clinical update. J Child Adolesc Psychiatr Nurs 17:85-86. https://doi.org/10.1111/j.1744-6171.2004.00085 .X

84. Chandramouli JB, Muller BA (2000) Case report of severe weight loss possibly associated with methylphenidate. J Pharm Technol 16:197-201. https://doi.org/10.1177/875512250001600 503

85. Blankfield RP (2012) Blood pressure, fluid retention and the cardiovascular risk of drugs. Future Cardiol 8:489-493. https://doi. org/10.2217/fca.12.39

86. Goldman RD (2010) ADHD stimulants and their effect on height in children. Can Fam Physician 56:145-146 (PMID:20154245)

87. Wilens TE, Adler LA, Adams J, Sgambati S, Rotrosen J, Sawtelle R, Utzinger L, Fusillo S (2008) Misuse and diversion of stimulants prescribed for ADHD: a systematic review of the literature. J Am Acad Child Adolesc Psychiatry 47:21-31. https:// doi.org/10.1097/chi.0b013e31815a56f1

88. Deconinck E, Verlinde K, Courselle P, De Beer JO (2012) A validated ultra high pressure liquid chromatographic method for the characterisation of confiscated illegal slimming products containing anorexics. J Pharm Biomed Anal 59:38-43. https:// doi.org/10.1016/j.jpba.2011.09.036

89. Vanhee C, Tuenter E, Kamugisha A, Canfyn M, Moens G, Courselle P, Pieters L, Deconinck E, Exarchou V (2018) Identification and quantification methodology for the analysis of suspected 
illegal dietary supplements: reference standard or no reference standard, that's the question. J Forensic Toxicol Pharmacol 7:1. https://doi.org/10.4172/2325-9841.1000156

90. Billiard M (2003) Modafinil: pharmacology and therapeutic perspectives. Rev Neurol (Paris) 159:122-125 (in French)

91. Chakravorty SS, Rye DB (2003) Narcolepsy in the older adult: epidemiology, diagnosis and management. Drugs Aging 20:361376. https://doi.org/10.2165/00002512-200320050-00005

92. Czeisler CA, Walsh JK, Roth T, Hughes RJ, Wright KP, Kingsbury L, Arora S, Schwartz JRL, Niebler GE, Dinges DF (2005) Modafinil for excessive sleepiness associated with shiftwork sleep disorder. N Engl J Med 353:476-486. https://doi. org/10.1056/NEJMoa041292

93. Keating GM, Raffin MJ (2005) Modafinil: a review of its use in excessive sleepiness associated with obstructive sleep apnoea/ hypopnoea syndrome and shift work sleep disorder. CNS Drugs 19:785-803. https://doi.org/10.2165/00023210-20051 9090-00005

94. Ballon JS, Feifel D (2006) A systematic review of modafinil: potential clinical uses and mechanisms of action. J Clin Psychiatry 67:554-566. https://doi.org/10.4088/JCP.v67n0406

95. Makris AP, Rush CR, Frederich RC, Kelly TH (2004) Wakepromoting agents with different mechanisms of action: comparison of effects of modafinil and amphetamine on food intake and cardiovascular activity. Appetite 42:185-195. https://doi. org/10.1016/j.appet.2003.11.003

96. Kim D (2012) Practical use and risk of modafinil, a novel waking drug. Environ Health Toxicol 27:e2012007. https://doi. org/10.5620/eht.2012.27.e2012007

97. Minzenberg MJ, Carter CS (2008) Modafinil: a review of neurochemical actions and effects on cognition. Neuropsychopharmacology 33:1477-1502. https://doi.org/10.1038/sj.npp.1301534

98. Lazenka MF, Negus SS (2017) Oral modafinil facilitates intracranial self-stimulation in rats. Behav Pharmacol 28:318-322. https ://doi.org/10.1097/FBP.0000000000000288

99. Avelar AJ, Cao J, Newman AH, Beckstead MJ (2017) Atypical dopamine transporter inhibitors R-modafinil and JHW 007 differentially affect D2 autoreceptor neurotransmission and the firing rate of midbrain dopamine neurons. Neuropharmacology 123:410-419. https://doi.org/10.1016/j.neuropharm.2017.06.016

100. Aronson J (2016) Rimonabant. Meyler's side effects of drugs, 16th edn. Elsevier, Amsterdam, pp 174-176. https://doi. org/10.1016/B978-0-444-53717-1.01712-1

101. Hossain MA, Pervin R, Debnath D, Bhuiyan MA (2019) Therapeutic treatment for controlling childhood obesity. In: Bagchi D (ed) Global perspectives on childhood obesity. Academic Press, Cambridge, pp 377-385

102. Ioannides-Demos LL, Piccenna L, McNeil JJ (2011) Pharmacotherapies for obesity: past, current, and future therapies. J Obes 2011:179674. https://doi.org/10.1155/2011/179674

103. Venhuis BJ, Vredenbregt MV, Kaun N, Maurin JK, Fijałek Z, de Kaste D (2011) The identification of rimonabant polymorphs, sibutramine and analogues of both in counterfeit Acomplia bought on the internet. J Pharm Biomed Anal 54:21-26. https:// doi.org/10.1016/j.jpba.2010.07.043

104. Trakulsrichai S, Sathirakul K, Auparakkitanon S, Krongvorakul J, Sueajai J, Noumjad N, Sukasem C, Wananukul W, Limsila P (2015) Pharmacokinetics of mitragynine in man. Drug Des Devel Ther 9:2421-2429. https://doi.org/10.2147/DDDT.S79658 (open access article)

105. Harun N, Hassan Z, Navaratnam V, Mansor SM, Shoaib M (2015) Discriminative stimulus properties of mitragynine (kratom) in rats. Psychopharmacology 232:2227-2238. https:// doi.org/10.1007/s00213-015-3866-5

106. Warner ML, Kaufman NC, Grundmann O (2016) The pharmacology and toxicology of kratom: from traditional herb to drug of abuse. Int J Legal Med 130:127-138. https://doi.org/10.1007/ s00414-015-1279-y

107. Veltri C, Grundmann O (2019) Current perspectives on the impact of Kratom use. Subst Abuse Rehabil 10:23-31. https:// doi.org/10.2147/sar.s164261 (open access article)

108. Manda VK, Avula B, Ali Z, Khan IA, Walker LA, Khan SI (2014) Evaluation of in vitro absorption, distribution, metabolism, and excretion (ADME) properties of mitragynine, 7-hydroxymitragynine, and mitraphylline. Planta Med 80:568-576. https://doi. org/10.1055/s-0034-1368444

109. Babu KM, McCurdy CR, Boyer EW (2008) Opioid receptors and legal highs: Salvia divinorum and Kratom. Clin Toxicol 46:146-152. https://doi.org/10.1080/15563650701241795

110. EMCDDA (2015) Kratom drug profile. http://www.emcdd a.europa.eu/publications/drug-profiles/kratom\#. Accessed $9 \mathrm{Jul}$ 2015

111. Simpson D (2013) Does Kratom cause weight loss?-Kratom online-buy Kratom capsules, powder and extract. https://krato monline.org/kratom-weight-loss/. Accessed 3 Jun 2020

112. Gunnar T, Ariniemi K, Lillsunde P (2005) Determination of 14 benzodiazepines and hydroxy metabolites, zaleplon and zolpidem as tert-butyldimethylsilyl derivatives compared with other common silylating reagents in whole blood by gas chromatography-mass spectrometry. J Chromatogr B 818:175-189. https:// doi.org/10.1016/j.jchromb.2004.12.032

113. Billes SK, Sinnayah P, Cowley MA (2014) Naltrexone/bupropion for obesity: an investigational combination pharmacotherapy for weight loss. Pharmacol Res 84:1-11. https://doi.org/10.1016/j. phrs.2014.04.004

114. Cooper JA, Tucker VL, Papakostas GI (2014) Resolution of sleepiness and fatigue: a comparison of bupropion and selective serotonin reuptake inhibitors in subjects with major depressive disorder achieving remission at doses approved in the European Union. J Psychopharmacol 28:118-124. https://doi. org/10.1177/0269881113514878

115. Monson K, Schoenstadt A (2007) Wellbutrin XL and weight loss. http://depression.emedtv.com/wellbutrin-xl/wellbutrin-xland-weight-loss.html. Accessed $10 \mathrm{Jul} 2015$

116. LeWine H (2014) FDA approves weight-loss drug Contrave. http://www.health.harvard.edu/blog/fda-approves-weight-lossdrug-contrave-201409127431. Accessed 10 Jul 2015

117. Santarsieri D, Schwartz TL (2015) Antidepressant efficacy and side-effect burden: a quick guide for clinicians. Drugs Context 4:1-12. https://doi.org/10.7573/dic.212290

118. Phattanawasin P, Sotanaphun U, Sukwattanasinit T, Akkarawaranthorn J, Kitchaiya S (2012) Quantitative determination of sibutramine in adulterated herbal slimming formulations by TLC-image analysis method. Forensic Sci Int 219:96-100. https ://doi.org/10.1016/j.forsciint.2011.12.004

119. Moreira APL, Motta MJ, Dal Molin TR, Viana C, de Carvalho LM (2013) Determination of diuretics and laxatives as adulterants in herbal formulations for weight loss. Food Addit Contam Part A 30:1230-1237. https://doi.org/10.1080/19440 049.2013.800649

120. Cadwallader A-B, de La Torre X, Tieri A, Botrè F (2010) The abuse of diuretics as performance-enhancing drugs and masking agents in sport doping: pharmacology, toxicology and analysis. Br J Pharmacol 161:1-16. https://doi.org/10.111 1/j.1476-5381.2010.00789.x

121. Heckman MA, Weil J, de Mejia EG (2010) Caffeine (1, 3, 7-trimethylxanthine) in foods: a comprehensive review on consumption, functionality, safety, and regulatory matters. J Food Sci 75:R77-R87. https://doi.org/10.1111/j.1750-3841.2010.01561.x

122. Onakpoya I, Hung SK, Perry R, Wider B, Ernst E (2011) The use of Garcinia extract (hydroxycitric acid) as a weight loss supplement: a systematic review and meta-analysis of 
randomised clinical trials. J Obes 2011:509038. https://doi. org/10.1155/2011/509038 (open access article)

123. Onakpoya I, Terry R, Ernst E (2011) The use of green coffee extract as a weight loss supplement: a systematic review and meta-analysis of randomised clinical trials. Gastroenterol Res Pract 2011:382852. https://doi.org/10.1155/2011/382852 (open access article)

124. Scheen AJ (2010) Cardiovascular risk-benefit profile of sibutramine. Am J Cardiovasc Drugs 10:321-334. https://doi. org/10.2165/11584800-000000000-00000

125. FDA (2018) FDA drug safety communication: FDA recommends against the continued use of Meridia (sibutramine). http://www. fda.gov/drugs/drugsafety/ucm228746.htm. Accessed 2 Jun 2020

126. European Medicines Agency (EMA) (2010) Sibutramine. https ://www.ema.europa.eu/en/medicines/human/referrals/sibutramin e. Accessed 3 Jun 2020

127. Australian Government. Department of Health. Therapeutic Goods Administration (TGA) (2010) Sibutramine (Reductil)_ withdrawal in Australia. https://www.tga.gov.au/alert/sibutramin e-reductil-withdrawal-australia. Accessed 2 Jun 2020

128. James WPT, Caterson ID, Coutinho W, Finer N, Van Gaal LF, Maggioni AP, Torp-Pedersen C, Sharma AM, Shepherd GM, Rode RA, Renz CL (2010) Effect of sibutramine on cardiovascular outcomes in overweight and obese subjects. N Engl J Med 363:905-917. https://doi.org/10.1056/NEJMoa1003114

129. FDA (1997) FDA announces withdrawal fenfluramine and dexfenfluramine (Fen-Phen). http://www.fda.gov/Drugs/DrugS afety/PostmarketDrugSafetyInformationforPatientsandProviders/ ucm179871.htm. Accessed 7 Jul 2015

130. Sinclair N (2000) EC bans medicines containing anorectic agents. http://www.icis.com/resources/news/2000/03/27/10888 7/ec-bans-medicines-containing-anorectic-agents/. Accessed 8 Jul 2015

131. Ball D, Kanter J (2003) European court overturns ban on a class of drugs for obesity. In: The Wall Str. J. http://www.wsj.com/artic les/SB1043752981653832544. Accessed 8 Jul 2015

132. Valsamakis G, Konstantakou P, Mastorakos G (2017) New targets for drug treatment of obesity. Annu Rev Pharmacol Toxicol 57:585-605. https://doi.org/10.1146/annurev-pharmtox-01071 6-104735

133. Sam AH, Salem V, Ghatei MA (2011) Rimonabant: from RIO to ban. J Obes 2011:432607. https://doi.org/10.1155/2011/43260 7 (open access article)

134. EMCDDA (2015) New psychoactive substances in Europe. An update from EU Early Warning System. https://doi. org/10.2810/372415

135. Mounteney J, Griffiths P, Sedefov R, Noor A, Vicente J, Simon R (2016) The drug situation in Europe: an overview of data available on illicit drugs and new psychoactive substances from European monitoring in 2015. Addiction 111:34-48. https://doi. org/10.1111/add.13056 (open access article)

136. Drug Enforcement Administration, Department of Justice (2016) Schedules of controlled substances: temporary placement of U-47700 into Schedule I. Final order. Fed Regist 81:79389-79393

137. FDA (2018) Statement from FDA Commissioner Scott Gottlieb, M.D., on the agency's scientific evidence on the presence of opioid compounds in kratom, underscoring its potential for abuse. https://www.fda.gov/news-events/press-announcements/ statement-fda-commissioner-scott-gottlieb-md-agencys-scientific -evidence-presence-opioid-compounds. Accessed 3 Jun 2020

138. Chan KB, Pakiam C, Rahim RA (2007) Psychoactive plant abuse: the identification of mitragynine in ketum and in ketum preparations. Bull Narc 57:249-256 (PMID:21338025)
139. Martino R, Malet-Martino M, Gilard V, Balayssac S (2010) Counterfeit drugs: analytical techniques for their identification. Anal Bioanal Chem 398:77-92. https://doi.org/10.1007/s0021 6-010-3748-y

140. SafeMedicines (2010) Partnership for safe medicines applauds Google's updated U.S. pharmaceutical advertising policy. http:// www.safemedicines.org/2010/02/partnership-for-safe-medicinesapplauds-googles-updated-us-pharmaceutical-advertising-polic y.html. Accessed 8 Jun 2015

141. FDA (2019) Tainted weight loss products. https://www.fda.gov/ drugs/medication-health-fraud/tainted-weight-loss-products. Accessed 3 Nov 2020

142. Palmer RB, Kim N-H, Dasgupta A (2000) Simultaneous determination of fenfluramine and phentermine in urine using gas chromatography mass spectrometry with pentafluoropropionic anhydride derivatization. Ther Drug Monit 22:418-422. https:// doi.org/10.1097/00007691-200008000-00009

143. FDA (2016) FDA drug safety communication: FDA revises warnings regarding use of the diabetes medicine metformin in certain patients with reduced kidney function. https://www.fda. gov/drugs/drug-safety-and-availability/fda-drug-safety-commu nication-fda-revises-warnings-regarding-use-diabetes-medicinemetformin-certain. Accessed 5 Sep 2020

144. Bailey CJ (2017) Metformin: historical overview. Diabetologia 60:1566-1576. https://doi.org/10.1007/s00125-017-4318-z

145. Zhu Z, Jiang W, Thompson MD, Echeverria D, McGinley JN, Thompson HJ (2015) Effects of metformin, buformin, and phenformin on the post-initiation stage of chemically induced mammary carcinogenesis in the rat. Cancer Prev Res 8:518-527. https ://doi.org/10.1158/1940-6207.CAPR-14-0121

146. Hankó B, Tukarcs É, Kumli P, Vincze Z (2005) Antidiabetic drug utilization in Hungary. Pharm World Sci 27:263-265. https://doi. org/10.1007/s11096-004-5804-1

147. Chou C-H, Cheng C-L, Huang C-C (2004) A validated HPLC method with ultraviolet detection for the determination of buformin in plasma. Biomed Chromatogr 18:254-258. https:// doi.org/10.1002/bmc.312

148. Rubiño MEG, Carrillo E, Alcalá GR, Domínguez-Martín A, Marchal JA, Boulaiz H (2019) Phenformin as an anticancer agent: challenges and prospects. Int J Mol Sci 20:3316. https:// doi.org/10.3390/ijms20133316 (open access article)

149. Ching CK, Lai CK, Poon WT, Wong ENP, Yan WW, Chan AYW, Mak TWL (2008) Hazards posed by a banned drugphenformin is still hanging around. Hong Kong Med J 14:50-54 (PMID:18239244) (open access article)

150. Home Office UK (2019) List of most commonly encountered drugs currently controlled under the misuse of drugs legislation. https://www.gov.uk/government/publications/controlled -drugs-list--2/list-of-most-commonly-encountered-drugs-curre ntly-controlled-under-the-misuse-of-drugs-legislation. Accessed 6 Sep 2020

151. Australian Government Department of Health, Therapeutic Goods Administration (2017) Scheduling delegate's interim decisions and invitation for further comment: ACCS/ACMS, March and July 2017. https://www.tga.gov.au/book-page/15-alpha-pyrro lidinovalerophenone-alpha-pvp-and-related-substances-methy lone-and-synthetic-cathinones. Accessed 6 Sep 2020

152. Deutscher Bundestag (2011) Gesetzentwurf der Bundesregierung. http://dip21.bundestag.de/dip21/btd/18/025/18025 81.pdf. Accessed 6 Sep 2020

153. International narcotics control board (2003) List of psychotropic substance under international control. https://www. incb.org/documents/Psychotropics/forms/greenlist/Green_list_ ENG_08673.pdf. Accessed 6 Sep 2020 
154. US Department of Justice (2016) Title 21 code of federal regulations: Part 1308-schedules of controlled substance. In: U.S. Dept. Justice, Drug Enforc. Adm., Diversion Control Division. https://www.deadiversion.usdoj.gov/21cfr/cfr/1308/1308_12. htm. Accessed 6 Sep 2020

155. Government of Canada, Department of Justice (2020) Controlled drugs and substances act (S.C 1996, c.19). https://laws-lois.justi ce.gc.ca/eng/acts/C-38.8/. Accessed 6 Sep 2020

156. Australian Government, Federal Register of Legislation (2016) Poisons Standard July 2016 (F2016L01071). https://www.legis lation.gov.au/Details/F2016L01071

157. UK Government (1971) Misuse of Drugs Act 1971 (c. 38): SCHEDULE 2: controlled drugs. https://www.legislation.gov.uk/ ukpga/1971/38/schedule/2/2019-04-01?timeline=true. Accessed 6 Sep 2020

158. New Zealand Medicines and Medical Devices Safety Authority (2017) Restrictions on the supply, prescribing or administration of medicines under the Medicines Act 1981 and Misuse of Drugs Regulations 1977. https://www.medsafe.govt.nz/profs/riss/restr ict.asp\#Methylphenidate, https://www.medsafe.govt.nz/profs/ riss/restrict.asp\#Clozapine. Accessed 6 Sep 2020

159. Swedish Ministry of Justice (1968) Narcotics penal code (1968: 64) (NSL). https://lagen.nu/1968:64. Accessed 6 Sep 2020

160. Japanese Narcotic Control Department (2020) Situation of drug abuse. http://www.ncd.mhlw.go.jp/en/index.html. Accessed 7 Sep 2020

161. Swedish Medical Products Agency (2019) Läkemedelsverkets föreskrifter (LVFS 2011:10) om förteckningar över narkotika. https://www.lakemedelsverket.se/4aa752/globalassets/dokument/ lagar-och-regler/hslf-fs/lvfs-2011-10-konsoliderad.pdf Accessed 7 Sep 2020

162. Australian Government, Federal Register of Legislation (2020) Poisons standard July 2020 (F2020L00899). https://www.legis lation.gov.au/Details/F2020L00899. Accessed 7 Sep 2020

163. Zhou L, Wang X, Liu W, Xiang P, Chen H (2020) Rapid identification of the "smart drug" modafinil in suspicious tablets by DART-HRMS combined with micropunching. Anal Methods 12:1430-1440. https://doi.org/10.1039/c9ay02624j

164. Government of Russia Federation (1998) Decision of the Government of the Russian Federation of No. 681 of June 30, 1998 on approval of the list of narcotic drugs, psychotropic substances and their precursors that shall be subject to control in the Russian Federation. https://www.wto.org/english/thewto_e/acc_e/rus_e/ WTACCRUS48A5_LEG_56.pdf. Accessed 7 Sep 2020

165. US Department of Health and Human Services (2017) Basis for the recommendation to control mitragynine and 7-hydroxymitragynine in Schedule I of the controlled substances act. https:// www.documentcloud.org/documents/5031552-HHS-kratom-lette r.html. Accessed 7 Sep 2020

166. New Zealand Legislation (2020) Medicines Regulations 1984 (SR 1984/143) (as of 1 April 2020). http://www.legislatio n.govt.nz/regulation/public/1984/0143/latest/DLM95668.html. Accessed 7 Sep 2020

167. National Institute of Health Sciences of Japan (2020) List of "Designated Substances" in Japan. https://www.mhlw.go.jp/ content/11120000/List.Nov.24.pdf. Accessed 17 Oct 2020

168. Legislation.gov.uk (2020) Psychoactive Substances Act 2016. https://www.legislation.gov.uk/ukpga/2016/2/contents. Accessed 7 Sep 2020

169. Strano-Rossi S, Colamonici C, Botrè F (2007) Detection of sibutramine administration: a gas chromatography/mass spectrometry study of the main urinary metabolites. Rapid Commun Mass Spectrom 21:79-88. https://doi.org/10.1002/rcm.2807

170. Ortiz RS, de Cássia MK, Holzschuh MH, Romão W, Limberger RP, Mayorga P (2013) Profiling counterfeit Cialis, Viagra and analogs by UPLC-MS. Forensic Sci Int 229:13-20. https://doi. org/10.1016/j.forsciint.2013.03.024

171. Csupor D, Boros K, Dankó B, Veres K, Szendrei K, Hohmann J (2013) Rapid identification of sibutramine in dietary supplements using a stepwise approach. Pharmazie 68:15-18. https:// doi.org/10.1691/ph.2013.2069

172. de Freitas SC, dos Santos MAZ, Berneira LM, Ortiz RS, de Pereira CMP (2019) Microwave-assisted extraction and differential scanning calorimetry in the chemical identification of sliming agents apprehended in the south region of Brazil. Sci Justice 59:190-198. https://doi.org/10.1016/j.scijus.2018.11.001

173. Rasmussen KE, Pedersen-Bjergaard S, Krogh M, Grefslie Ugland H, Grønhaug T (2000) Development of a simple in-vial liquidphase microextraction device for drug analysis compatible with capillary gas chromatography, capillary electrophoresis and highperformance liquid chromatography. J Chromatogr A 873:3-11. https://doi.org/10.1016/S0021-9673(99)01163-2

174. Ho TS, Pedersen-Bjergaard S, Rasmussen KE (2002) Recovery, enrichment and selectivity in liquid-phase microextraction: comparison with conventional liquid-liquid extraction. J Chromatogr A 963:3-17. https://doi.org/10.1016/S0021-9673(02)00215-7

175. Snow N-H (2000) Solid-phase micro-extraction of drugs from biological matrices. J Chromatogr A 885:445-455. https://doi. org/10.1016/S0021-9673(00)00192-8

176. Sporkert F, Pragst F (2000) Use of headspace solid-phase microextraction (HS-SPME) in hair analysis for organic compounds. Forensic Sci Int 107:129-148. https://doi.org/10.1016/S0379 -0738(99)00158-9

177. Bielicka-Daszkiewicz K, Voelkel A (2009) Theoretical and experimental methods of determination of the breakthrough volume of SPE sorbents. Talanta 80:614-621. https://doi. org/10.1016/j.talanta.2009.07.037

178. Zhao L, Lee HK (2001) Application of static liquid-phase microextraction to the analysis of organochlorine pesticides in water. J Chromatogr A 919:381-388. https://doi.org/10.1016/S0021 -9673(01)00816-0

179. Shen G, Lee HK (2002) Hollow fiber-protected liquid-phase microextraction of triazine herbicides. Anal Chem 74:648-654. https://doi.org/10.1021/ac010561o

180. Bae J-W, Choi C-I, Jang C-G, Lee S-Y (2011) Simultaneous determination of sibutramine and its active metabolites in human plasma by LC-MS/MS and its application to a pharmacokinetic study. Biomed Chromatogr 25:1181-1188. https://doi. org/10.1002/bmc. 1587

181. Adaway JE, Keevil BG, Owen LJ (2015) Liquid chromatography tandem mass spectrometry in the clinical laboratory. Ann Clin Biochem 52:18-38. https://doi.org/10.1177/000456321455767 8 (open access article)

182. Gathungu R-M, Kautz R, Kristal B-S, Bird S-S, Vouros P (2020) The integration of LC-MS and NMR for the analysis of low molecular weight trace analytes in complex matrices. Mass Spectrom Rev 39:35-54. https://doi.org/10.1002/mas.21575

183. Chesnut SM, Salisbury JJ (2007) The role of UHPLC in pharmaceutical development. J Sep Sci 30:1183-1190. https://doi. org/10.1002/jssc.200600505

184. Dong MW, Guillarme D (2013) Newer developments in HPLC impacting pharmaceutical analysis: a brief review. Am Pharm Rev 16:36-43 (open access article)

185. Stypułkowska K, Błażewicz A, Maurin J, Sarna K, Fijałek Z (2011) X-ray powder diffractometry and liquid chromatography studies of sibutramine and its analogues content in herbal dietary supplements. J Pharm Biomed Anal 56:969-975. https://doi. org/10.1016/j.jpba.2011.08.028

186. Núñez O, Gallart-Ayala H, Martins CPB, Lucci P, Busquets R (2013) State-of-the-art in fast liquid chromatography-mass 
spectrometry for bio-analytical applications. J Chromatogr B 927:3-21. https://doi.org/10.1016/j.jchromb.2012.12.031

187. Jemal M (2000) High-throughput quantitative bioanalysis by LC/MS/MS. Biomed Chromatogr 14:422-429. https://doi. org/10.1002/1099-0801(200010)14:6\%3c422::AID-BMC25 \%3e3.0.CO;2-I

188. Kim SH, Lee J, Yoon T, Choi J, Choi D, Kim D, Kwon SW (2009) Simultaneous determination of anti-diabetes/anti-obesity drugs by LC/PDA, and targeted analysis of sibutramine analog in dietary supplements by LC/MS/MS. Biomed Chromatogr 23:1259-1265. https://doi.org/10.1002/bmc.1248

189. Bogusz MJ, Hassan H, Al-Enazi E, Ibrahim Z, Al-Tufail M (2006) Application of LC-ESI-MS-MS for detection of synthetic adulterants in herbal remedies. J Pharm Biomed Anal 41:554564. https://doi.org/10.1016/j.jpba.2005.12.015

190. Chen Y, Zhao L, Lu F, Yu Y, Chai Y, Wu Y (2009) Determination of synthetic drugs used to adulterate botanical dietary supplements using QTRAP LC-MS/MS. Food Addit Contam Part A 26:595-603. https://doi.org/10.1080/02652030802641880

191. Li Y, Zhang H, Hu J, Xue F, Li Y, Sun C (2012) A GC-EI-MSMS method for simultaneous determination of seven adulterants in slimming functional foods. J Chromatogr Sci 50:928-933. https://doi.org/10.1093/chromsci/bms092

192. Arbouche N, Batt M-O, Raul J-S, Kintz P (2020) Development of a new GC-MS/MS method for the determination of metformin in human hair. Drug Test Anal 12:1380-1386. https:// doi.org/10.1002/dta.2866

193. Goedecke C, Fettig I, Piechotta C, Philipp R, Geissen SU (2017) A novel GC-MS method for the determination and quantification of metformin in surface water. Anal Methods 9:1580-1584. https ://doi.org/10.1039/C6AY02606K

194. Liu S-Y, Woo S-O, Koh H-L (2001) HPLC and GC-MS screening of Chinese proprietary medicine for undeclared therapeutic substances. J Pharm Biomed Anal 24:983-992. https://doi. org/10.1016/S0731-7085(00)00571-9

195. Che Sulaiman IS, Chieng BW, Pojol FE, Ong KK, Abdul Rashid JI, Wan Yunus WMZ, Mohd Kasim NA, Abdul Halim N, Mohd Noor SA, Knight VF (2020) A review on analysis methods for nerve agent hydrolysis products. Forensic Toxicol 38:297-313. https://doi.org/10.1007/s11419-019-00513-x (open access article)

196. Voeten RLC, Ventouri IK, Haselberg R, Somsen GW (2018) Capillary electrophoresis: trends and recent advances. Anal Chem 90:1464-1481. https://doi.org/10.1021/acs.analchem.8b000 15 (open access article)

197. Lamalle C, Marini RD, Debrus B, Lebrun P, Crommen J, Hubert P, Servais AC, Fillet M (2012) Development of a generic micellar electrokinetic chromatography method for the separation of 15 antimalarial drugs as a tool to detect medicine counterfeiting. Electrophoresis 33:1669-1678. https://doi.org/10.1002/ elps.201100621

198. Marini RD, Rozet E, Montes MLA, Rohrbasser C, Roht S, Rhème D, Bonnabry P, Schappler J, Veuthey JL, Hubert P, Rudaz S (2010) Reliable low-cost capillary electrophoresis device for drug quality control and counterfeit medicines. J Pharm Biomed Anal 53:1278-1287. https://doi.org/10.1016/j.jpba.2010.07.026

199. Piette V, Parmentier F (2002) Analysis of illicit amphetamine seizures by capillary zone electrophoresis. J Chromatogr A 979:345-352. https://doi.org/10.1016/s0021-9673(02)01405-x

200. Akamatsu S, Mitsuhashi T (2014) Simultaneous determination of pharmaceutical components in dietary supplements for weight loss by capillary electrophoresis tandem mass spectrometry. Drug Test Anal 6:426-433. https://doi.org/10.1002/dta.1524

201. dos Santos VB, Daniel D, Singh M, do Lago CL (2016) Amphetamine and derivatives in natural weight loss pills and dietary supplements by capillary electrophoresis-tandem mass spectrometry. J Chromatogr B 1038:19-25. https://doi.org/10.1016/j.jchro mb.2016.10.019

202. Deconinck E, Sacré P-Y, Courselle P, De Beer JO (2013) Chromatography in the detection and characterization of illegal pharmaceutical preparations. J Chromatogr Sci 51:791-806. https:// doi.org/10.1093/chromsci/bmt006

203. Rocco A, Donati E, Touloupakis E, Aturki Z (2018) Miniaturized separation techniques as analytical methods to ensure quality and safety of dietary supplements. TrAC Trends Anal Chem 103:156-183. https://doi.org/10.1016/j.trac.2018.04.004

204. Toudeshki RM, Dadfarnia S, Haji Shabani AM (2019) Surface molecularly imprinted polymer on magnetic multi-walled carbon nanotubes for selective recognition and preconcentration of metformin in biological fluids prior to its sensitive chemiluminescence determination: central composite design optimization. Anal Chim Acta 1089:78-89. https://doi.org/10.1016/j. aca.2019.08.070

205. Song A, Wang J, Lu G, Jia Z, Yang J, Shi E (2018) Oxidized multiwalled carbon nanotubes coated fibers for headspace solidphase microextraction of amphetamine-type stimulants in human urine. Forensic Sci Int 290:49-55. https://doi.org/10.1016/j.forsc iint.2018.06.031

206. UNODC Global SMART programme (2013) The challenge of new psychoactive substances. https://www.unodc.org/documents/ scientific/NPS_Report.pdf. Accessed 7 Sep 2020

207. Alshaikhi AM, Alharthi N, Alzhrani S (2018) Sibutramine (hidden ingredient)—induced psychosis, associated with the use of herbal slimmingproduct: a case report. J Psychol Neuropsychiatry Std 1:101 (open access article)

208. Bunya N, Sawamoto K, Uemura S, Kyan R, Inoue H, Nishida J, Kouzu H, Kokubu N, Miura T, Narimatsu E (2017) Cardiac arrest caused by sibutramine obtained over the Internet: a case of a young woman without pre-existing cardiovascular disease successfully resuscitated using extracorporeal membrane oxygenation. Acute Med Surg 4:334-337.https://doi.org/10.1002/ ams 2.275 (open access article)

209. Shapira B, Goldstein L, Reshef A, Poperno A (2016) A rare case of psychomotor disturbances linked to the use of an adulterated dietary supplement containing sibutramine. Clin Neuropharmacol 39:154-156. https://doi.org/10.1097/WNF.000000000000014 1

210. Pamukcu Gunaydin G, Dogan NO, Levent S, Kurtoglu Celik G (2015) Herbal weight loss pill overdose: sibutramine hidden in pepper pill. Case Rep Emerg Med 2015:213874. https://doi. org/10.1155/2015/213874 (open access article)

211. Vecchio S, Giampreti A, Petrolini V-M, Lonati D, Protti A, Papa P, Rognoni C, Valli A, Rocchi L, Rolandi L, Manzo L, Locatelli C-A (2014) Metformin accumulation: lactic acidosis and high plasmatic metformin levels in a retrospective case series of 66 patients on chronic therapy. Clin Toxicol 52:129-135. https://doi. org/10.3109/15563650.2013.860985

212. Khazan M, Hedayati M, Askari S, Azizi F (2013) Adulteration of products sold as Chinese herbal medicines for weight loss with thyroid hormones and PCP. J Herb Med 3:39-43. https://doi. org/10.1016/j.hermed.2012.11.003

213. Heo SH, Kang M-H (2013) A case of dilated cardiomyopathy with massive left ventricular thrombus after Use of a sibutramine-containing slimming product. Korean Circ J 43:632-635. https://doi.org/10.4070/kcj.2013.43.9.632 (open access article)

214. Lam PK, Leung KS, Wong TW, Lee HHC, Tang MHY, Mak TWL (2012) Serotonin syndrome following overdose of a non-prescription slimming product containing sibutramine: 
a case report. Hum Exp Toxicol 31:414-417. https://doi. org/10.1177/0960327111431704

215. Ching CK, Lam YH, Chan AYW, Mak TWL (2012) Adulteration of herbal antidiabetic products with undeclared pharmaceuticals: a case series in Hong Kong. Br J Clin Pharmacol 73:795-800. https://doi.org/10.1111/j.1365-2125.2011.04135.x (open access article)

216. Vitalone A, Menniti-Ippolito F, Moro PA, Firenzuoli F, Raschetti R, Mazzanti G (2011) Suspected adverse reactions associated with herbal products used for weight loss: a case series reported to the Italian National Institute of Health. Eur J Clin Pharmacol 67:215-224. https://doi.org/10.1007/s00228-010-0981-4

217. Chong CSY (2010) Psychosis related to the use of sibutramine disguised as over-the-counter herbal weight loss remedies: a report of two patients. East Asian Arch Psychiatry 20:186-189 (PMID:22348928) (open access article)

218. Müller D, Weinmann W, Hermanns-Clausen M (2009) Chinese slimming capsules containing sibutramine sold over the Internet. Dtsch Arztebl Int 106:218-222. https://doi.org/10.3238/arzte bl.2009.0218 (open access article)

219. Yim K-MA, Ng HW, Chan C-K, Yip G, Lau FL (2008) Sibutramine-induced acute myocardial infarction in a young lady. Clin Toxicol 46:877-879. https://doi.org/10.1080/1556365080 2136258 (open access article)

220. Poon WT, Ng SW, Lai CK, Chan YW, Mak WL (2008) Factitious thyrotoxicosis and herbal dietary supplement for weight reduction. Clin Toxicol 46:290-292. https://doi.org/10.1080/15563 650701381179

221. Hung Y-M, Chang J-C (2006) Weight-reducing regimen associated with polymorphic ventricular tachycardia. Am J Emerg Med 24:714-716. https://doi.org/10.1016/j.ajem.2006.02.004

222. Jung J, Hermanns-Clausen M, Weinmann W (2006) Anorectic sibutramine detected in a Chinese herbal drug for weight loss. Forensic Sci Int 161:221-222. https://doi.org/10.1016/j.forsc iint.2006.02.052

223. Lai V, Smith A, Thorburn D, Raman VS (2006) Severe hepatic injury and adulterated Chinese medicines. Br Med J 332:304305. https://doi.org/10.1136/bmj.332.7536.304-b

224. Hsiao AL, Santucci KA, Seo-Mayer P, Mariappan MR, Hodsdon ME, Banasiak KJ, Baum CR (2005) Pediatric fatality following ingestion of dinitrophenol: postmortem identification of a "dietary supplement." Clin Toxicol 43:281-285. https://doi. org/10.1081/CLT-58946

225. Lau G, Lo DST, Yao YJ, Leong HT, Chan CL, Chu SS (2004) A fatal case of hepatic failure possibly induced by nitrosofenfluramine. Med Sci Law 44:252-263. https://doi.org/10.1258/ rsmmsl.44.3.252
226. Adachi M, Saito H, Kobayashi H, Horie Y, Kato S, Yoshioka M, Ishii $\mathrm{H}$ (2003) Hepatic injury in 12 patients taking the herbal weight loss aids Chaso or Onshido. Ann Intern Med 139:488. https://doi.org/10.7326/0003-4819-139-6-200309160-00012

227. Nakadai A, Inagaki H, Minami M, Takahashi H, Namme R, Ohsawa M, Ikegami S (2003) Determination of the optical purity of $N$-nitrosofenfluramine found in the Chinese slimming diet. Yakugaku Zasshi 123:805-809. https://doi.org/10.1248/yakus hi.123.805 (in Japanese with English abstract; open access article)

228. Corns C, Metcalfe K (2002) Risks associated with herbal slimming remedies. J R Soc Promot Health 122:213-219. https://doi. org/10.1177/146642400212200407

229. Ali R, Alminderej FM, Saleh SM (2020) A simple, quantitative method for spectroscopic detection of metformin using gold nanoclusters. Spectrochim Acta A Mol Biomol Spectrosc 241:118744. https://doi.org/10.1016/j.saa.2020.118744

230. Moradi M, Sohrabi MR, Mortazavinik S (2020) Simultaneous ultra-trace quantitative colorimetric determination of antidiabetic drugs based on gold nanoparticles aggregation using multivariate calibration and neural network methods. Spectrochim Acta Part A Mol Biomol Spectrosc 234:118254. https://doi.org/10.1016/j. saa.2020.118254

231. Ma D, Quan J, Du J (2014) Gold nanoparticles-enhanced chemiluminescence determination of fenfluramine. J Chin Chem Soc 61:425-431. https://doi.org/10.1002/jccs.201300407

232. Pundir CS, Deswal R, Narwal V, Narang J (2018) Quantitative analysis of metformin with special emphasis on sensors: a review. Curr Anal Chem 14:438-445. https://doi.org/10.2174/15734 11013666170907150509 (open access article)

233. Ghanbari MH, Sharafi P, Nayebossadr S, Norouzi Z (2020) Utilizing a nanocomposite consisting of zinc ferrite, copper oxide, and gold nanoparticles in the fabrication of a metformin electrochemical sensor supported on a glassy carbon electrode. Microchim Acta 187:557. https://doi.org/10.1007/s00604-020-04529 $-8$

234. dos Santos WTP, Compton RG (2019) A simple method to detect the stimulant modafinil in authentic saliva using a carbon-nanotube screen-printed electrode with adsorptive stripping voltammetry. Sens Actuators B Chem 285:137-144. https://doi. org/10.1016/j.snb.2019.01.047

Publisher's Note Springer Nature remains neutral with regard to jurisdictional claims in published maps and institutional affiliations. 